\title{
Wage Divergence between the Rocky Mountain States and the U.S.: Idaho Measures and Sources, 2001-2009*
}

\author{
Stephen C. Cooke and Bharathkumar A. Kulandaisamy ${ }^{+}$
}

ABSTRACT. In 2005, the Rocky Mountain States (Colorado, Idaho, Montana, Utah, and Wyoming) average annual wage per job was about $\$ 4,000$ less than the U.S. average. In 2009, Idaho's average wage per job was $\$ 10,700$ less. The difference in wage elasticities measures, sector bias, and Theil inequality indices were used to identify the sectors that were the source of the growing wage gap between Idaho and the U.S. across 81 sectors. Idaho's wage gap was the result of positive sector bias on employment growth in influential low-wage sectors and negative sector bias on employment growth and the low level of wages in the influential high-wage sectors. The economy of the Rocky Mountain region can be characterized as caught in a low-skill/low-wage equilibrium trap.

Key Words: Wage, Wage Distribution, Technological Choice, Education, Labor Productivity, Skill-Bias, Wage Gap, Wage Inequality

JEL Codes: J21, R12, R23

\section{THE WAGE GAP}

In 2005, the average annual wage in Rocky Mountain states - Colorado, Idaho, Montana, Utah, and Wyoming-was about $\$ 4,000$ below the U.S. average (see Table 1). It has been below the U.S. average since the late 1970s. There had been significant variation across the four states, however. Colorado was the only state in the region with an average wage equal to the nation's. Colorado also boasted the highest growth in wages, the largest proportion of high-skill jobs in the economy, and the largest share of college graduates in the labor force. At the other extreme, Montana's average wages was about $\$ 11,000$ below the U.S. average with the lowest wage and employment growth, as well as a declining population. The average wage and related socioeconomic indicators in Utah, Wyoming, and Idaho fell between these two extremes.

The contrast between the Rocky Mountain region's modest wage performance and its vigorous employment and population growth overall is striking: employment growth in the region averaged more than a percentage point above the nation's growth rate; population growth lagged slightly that for employment. Employment and population dynamics also vary across the Rocky Mountain States. But, according to a Granger causality test, ${ }^{1}$ in several states such as Idaho and Utah, population growth drove the employment growth. Population grew particularly in the small

\footnotetext{
* The authors gratefully acknowledge the helpful comments and suggestions of the RRS editors Michael Lahr and Robert Gibbs, the three anonymous reviewers, as well as those from Judy Brown, Philip Watson and Chen Chen. This research was supported

+ Respectively Associate Professor and graduate of the Department of Agricultural Economics and Rural Sociology, University of Idaho.

Contact author: Stephen Cooke, Department of Agricultural Economics and Rural Sociology, University of Idaho, Moscow, ID 83843. E-mail:scooke@uidaho.edu.

${ }^{1}$ Two data series are Granger causal if the lagged effect of the second series anticipates movements in the first and if the second contributes to explaining the first beyond its own lagged effects. In both Idaho and Utah, population growth and wage growth are correlated (.58 and .76 , respectively) and the Granger causality between these measures runs from population to wage growth ( $p=.001$ and .016 , respectively).
}

(C) Southern Regional Science Association 2011. 
TABLE 1. Indicators of Economic Performance for the Rocky Mountain States as Different from the U.S., 1971-2007

\begin{tabular}{|c|c|c|c|c|c|c|}
\hline Indicator & RM & $\mathrm{CO}$ & ID & MT & UT & WY \\
\hline Wages/worker $^{1}$ & \multicolumn{6}{|c|}{$(\$, 2005=100)$} \\
\hline mean & $-2,703$ & 85 & $-6,437$ & $-7,206$ & $-4,406$ & $-3,762$ \\
\hline median & $-3,285$ & -266 & $-6,445$ & $-7,980$ & $-4,796$ & $-4,730$ \\
\hline st.dev. & 1097 & 881 & 1927 & 3110 & 1687 & 3506 \\
\hline 2005 & $-4,003$ & 858 & $-9,309$ & $-11,054$ & $-7,085$ & $-7,081$ \\
\hline Wages/worker ${ }^{1 *}$ & \multicolumn{6}{|c|}{ Growth rate State-U.S.(\%) (year over year) } \\
\hline mean & 0.0 & 0.2 & -0.2 & -0.4 & -0.1 & 0.1 \\
\hline median & 0.0 & 0.3 & -0.3 & -0.4 & -0.2 & 0.0 \\
\hline st.dev. & 0.5 & 0.4 & 0.4 & 0.8 & 0.5 & 1.7 \\
\hline \multicolumn{7}{|l|}{ Employment $^{1^{*}}$} \\
\hline mean & 1.2 & 1.2 & 1.2 & 0.3 & 1.7 & 0.6 \\
\hline median & 1.1 & 1.1 & 1.5 & 0.5 & 1.7 & 0.6 \\
\hline st.dev. & 0.8 & 0.9 & 1.0 & 0.9 & 0.5 & 1.8 \\
\hline \multicolumn{7}{|l|}{ Population $^{2 *}$} \\
\hline mean & 0.9 & 1.1 & 0.9 & -0.2 & 1.4 & 0.2 \\
\hline median & 0.9 & 1.0 & 1.0 & -0.2 & 1.3 & -0.3 \\
\hline st.dev. & 0.5 & 0.5 & 0.6 & 0.3 & 0.5 & 1.4 \\
\hline 2008 & \multicolumn{6}{|c|}{ Proportion State-U.S. (\%) } \\
\hline College Ed. Workers ${ }^{4}$ & 3.3 & 7.6 & -3.4 & -0.3 & 1.2 & -3.9 \\
\hline High-Skill Jobs ${ }^{3 * *}$ & -0.1 & 2.3 & 0.0 & -1.1 & -3.1 & -4.7 \\
\hline Education gap & 3.3 & 5.4 & -3.4 & 0.9 & 4.4 & 0.8 \\
\hline
\end{tabular}

Sources: 1. U.S. Bureau of Economic Analysis - Wage and Employment Data and Personal Consumption Expenditure Deflator; 2. U.S. Census Bureau; 3. U.S. Bureau of Labor Statistics (various years); 4. U.S. Census Bureau (2011), educational attainment, 2005-2007 average.

Notes: * Short-term fluctuations in annual data smoothed with a Hodrick-Prescott filter, $\lambda=100$

** Occupations: Management, Business and financial operations, Computer and mathematical science, Architecture and engineering, Life, physical, and social science, Community and social services, Legal, Education, training, and library, Arts, design, entertainment, sports, and media, Healthcare practitioners and technical.

towns of the Rocky Mountain States because of a general restructuring of the California economy; many Californians, including retirees, left the state at the end of the Cold War (Plane, Henrie, and Perry, 2005).The closing of defense plants in Southern California along with the amenity-rich areasof the Rocky Mountain region provided the push and the pull on population and employment growth, at least in Idaho and Utah (McGranahan, 1999).

Idaho's economy represents a microcosm of the economic problems within the Rocky Mountain region. Idaho has fast-growing population and employment like Colorado, low wage growth like Utah, low wages like Montana, and a small proportion of college-educated labor force like Wyoming, yet almost the same proportion of high-skill jobs as Colorado. Based on these similarities, insights into Idaho's economy can shed light on the problems faced by the region as a whole. We begin by examining the accepted narrative within Idaho of the state's low wages.

The 1979 to 1982 recession changed the perception of the economy - if not the realitythat people held in the Rocky Mountain region. The accepted view of the regional economy changed from one dominated by the high-paying natural-resource sectors of timber, mining, and agriculture to one dependent on low-wage service and manufacturing jobs due to the loss of highwage natural resource jobs. A good example of this narrative is contained in the article "Why 
Idaho Wages Went South" published by the Idaho Department of Labor in which Fick (2008, pp. 1-2) states: ${ }^{2}$

The dramatic decline in the state's natural resource industries over the past 30 years took with it the comparatively high-paying jobs timber and mining provided, especially in rural Idaho.

In many communities, those jobs have not been replaced, and workers have migrated to the cities for construction, light manufacturing, and service sector jobs...Sawmill and mining towns were hit the hardest. Their well-paid resource workers had been propping up the average statewide wage in the 1970s, and the sector's collapse was a major contributor to the decline in the statewide average since. New jobs and replacement jobs came to most of those communities but with much smaller paychecks...The high wages in rural Idaho's mill and mining towns during the 1970s [were] wages that exceeded national averages.

Fick's conjecture is that low-wage construction, manufacturing, and service sector jobs replaced high-wage natural-resource jobs in Idaho between 1977 and 2005. This explanation presumes that: 1) Idaho's average wages by sector have historically hovered around the sectors' U.S. averages and 2) the change in employment from high- to low-wage sectors alone was responsible for the state's declining average wage. According to Fick, Idaho's low average wage is the result of its relatively large share of low-wage jobs rather than of any decline in real wages.

This article uses three sets of wage and employment indices (Tornquist input, sector-bias, and partial-Theil inequality indices) to measure the relatively slow wage growth in Idaho compared to the U.S. and to examine Fick's description of Idaho's economy more closely. Specifically, we test Redding (1996) and Scicchitao's (2009) "low-skill equilibrium trap" hypothesis, which describes a process of stagnant skill change in regions with relatively few high-skill jobs or workers. By using the Tornquist wage index, the paper then measures wage growth as the result of substitution between low-skill/low-wage labor and high-skill/high-wage labor while holding technology constant. The wage and employment sector-bias indices measure technology-induced movement in wages and employment. Partial-Theil inequality indices estimates the effects of changing wages and employment on wage inequality: this complementary approach is used to confirm or refute the results of the Tornquist and sector -bias indices. We use these mechanisms to determine the cause of Idaho's wage divergence from the U.S. We present the Tornquist and sector-bias indices of change in wage per job, employment, and wages paid along with a list of the sectors primarily responsible for these changes. This discussion is followed by a description of the sector-level data used and the results of our analysis. We conclude with a new narrative of the growing wage gap in Rocky Mountain region along with several policy recommendations.

\section{THEORIES OF WAGE EQUILIBRIUM}

Observed disparities in average wages across regions can be viewed either as disequilibrium in search of an equilibrating process or as distinct equilibria in need of a causal explanation. For example, Knapp and Graves (1989) argue that amenities play a key role in

\footnotetext{
${ }^{2}$ Fick calculated the real average wage per Idaho worker in 1977 and 2005 both overall and in three sectors: sawmills, mines, and combined retail and services. He observed: 1) that average wages in sawmills and mines were above average, while those in retail and services sectors were below, and 2) the share of the wage bill going to employment in sawmills and mines decreased, while that in retail and services increased. From this, he inferred that the shift in employment from timber and mining to retail \& services caused the decline in average wages in Idaho (personal correspondence).
} 
equilibrium models of wage differentials in regional development in contrast to trade theories that start with a presumption of disequilibrium that needs to be reconciled by labor migration.

We begin with an assumption of wage disequilibrium in which the adjustment of average wages proceeds in a combination of two processes: the one by an increase in labor productivity and the other by a shift in competitive advantage. The marginal productivity theory of labor predicts that changes in worker efficiency should be accompanied by proportional changes in real wages. If more-skilled labor replaces less skilled, then the wage increase is a measure of the added labor productivity. The second process is through shifts in the economy's mix and concentration of sectoral production, since the economy's sectors can display very different average rates of pay. Changes in an economy's competitive advantage determine the economy's industry mix and each of its sector's relative size. Such change is based on the region's relative quantity and quality of its factor endowment (natural resources, labor, and capital), the relative price of those factors, and the region's institutional arrangements (Heckscher, 1995; North, 1990; Ohlin, 1967). An increase in a high-wage sector's share of total wages paid implies an increase in its competitive advantage. Solow and Heckscher-Ohlin argue that the capital/labor ratios across sectors converge in the absence of transactions costs and other institutional barriers. They predict wages of all sectors should asymptotically approach the economy's mean wage (Murphy and Welch, 1993; Solow, 1956).

Kim (1998) has shown that average wages across regions of the U.S. converged over the prior 150 years even though the rank order of regions' average wages remained largely unchanged. Carlino and Mills (1996) determined that wages and earnings in the states and regions of the U.S. had converged by 1946. They argued that the wage divergence observed between 1978 and 1988 (the tail end of their study period) was likely a temporary deviation from historic trends. In the Rocky Mountain states, wage growth convergence appears to hold for Colorado, but not for Idaho, Montana, Utah, and Wyoming.

One variant of the disequilibrium theme is perpetual disequilibrium among regions. Romer (1986) and Lucas (1988) argue that productivity is enhanced by external economies of scale; Krugman (1991) makes a similar argument for competitive advantage. These theories suggest selfperpetuating processes in which the average wages of regions can continue to diverge.

Baumol (1967) presents yet another permanent wage disequilibrium theory-one across sectors. He argues that labor has fundamentally different roles across sectors, which affects sector's potential to display productivity gains. For example, Baumol (1967, p. 416) suggests that labor in airplane manufacturing is "an incidental requisite for the attainment of the final product," while labor in a concert performance is "an end in itself, in which quality is judged directly in terms of the amount of labor." Because of this, he concludes that labor productivity gains will generally continue to be greater in manufacturing than in services.

In the U.S. from the 1970s to the 1990s, wages grew slowly; they also diverged by region. Bluestone and Harrison (1988) concluded that the U.S. was engaged in an intense restructuring. They argued that low-paying service-sector jobs were replacing high-paying manufacturing jobs (inducing Baumol's disease); the latter jobs were being lost due to outsourcing the intermediate steps of production. Their de-industrialization hypothesis foreshadowed the standard narrative of economic restructuring in Idaho.

However, studying natural amenity-rich rural counties in the U.S., Deller et al. (2001) find that concerns appear to be "misplaced" regarding the change in quality of jobs created from 
substituting service-oriented jobs for those in resource extractive sectors; in fact, these counties experience "higher overall levels of growth." Deller et al.'s conclusion contradicts Fick's conjecture regarding Idaho's wage gap without providing either a process or an explanation as to how to close it.

Next, we examine the case in which differences in average wages across regions represent equilibria in need of an explanation. Differences in regional wages and housing costs are often explained by the discounted or capitalized level of amenities. Rosen (1979) argues that an equilibrium wage for a region is an inverse function of the difference in cost of living and quality of life that labor experiences across cities. Roback (1988) finds that differences in the cost of living exacerbate rather than explain wage differences across regions: the same dynamic that entices labor to accept lower wages in a high-amenity region also causes property owners to expect a higher return on an equal quantity of housing (also see Partridge et al., 2009).

Evans (1977) demonstrates that economic rent determined by "well-functioning land markets" is not an accurate measure of amenities of a city: fragmented land-use controls result in over-development. As predicted by Evans, Rosen (1979) shows that real wages and city density are inversely correlated to one another. Roback (1988) also recognizes the possibility that a region's natural amenities not only can have positive utility for labor but can also help increase worker productivity for firms - making the net effect of amenities on wages ambiguous. Furthermore, Gabriel and Rosenthal (2008) show that the amenities that attract workers to a region are not necessarily the same characteristics that attract firms.

Using data from a mail survey, Dickie and Gerking (1987) found that detailed education, work, and personal characteristics enabled an accounting of nearly all the regional differences in wages across the U.S. Still, Roback (1988) found within the U.S. that only the West continued to exhibit significantly lower earnings (7 percent) after correcting for cost of living and amenity differences, particularly among college-educated workers. Another causal explanation for the difference in equilibrium wages is associated with the distance across cities of different sizes within a region. Partridge et al. (2009) found that the cumulative distance from increasingly larger urban areas and associated loss of "agglomeration benefits" reduces the combined level of earnings and housing costs by 9 to 18 percent. For example, in 2000, 30 to 40 percent of the population in Wyoming, Montana, and Idaho lived in communities with more than 65,000 residents compared to 78 to 84 percent of the population in Utah and Colorado (U.S. Census Bureau, 2009b). By assuming the wages of all workers in Idaho are subject to this distance penalty, then the 2005 distance-adjusted wage loss is still between $\$ 2,600$ and $\$ 6,700$ per worker or $\$ 1.7$ billion to $\$ 4.4$ billion for all workers the state.

Based on the above review of the wage literature, we assume a homogeneous level of amenities throughout the Rocky Mountain region including Idaho in which the cost of living only exacerbates wage differences. Assuming away distinct equilibrium explanations of wage differences implies accepting a disequilibrium wage theory including a process of reconciling the difference between the U.S. average wage and its equivalents for each of the Rocky Mountain states.

We test Redding's (1996) and Scicchitao's (2009) (henceforth, "R-S”) disequilibrium wage theory across sectors of a region. It holds that chronic low wages in a developed economy are a symptom of a "low-skill equilibrium trap." A low-skill economy is one marked with fewer highskill jobs across sectors, a labor force with below-average education and training, low labor 
productivity, and hence low wages. The high-skill equilibrium is characterized as "firms producing high quality, specialized goods and services [that] require a well-qualified workforce capable of rapid adjustment in the work process and continual product innovation" (Finegold and Soskice, 1988).

In light of R-S theory, Colorado appears to have made the transition from a low-skill to a high-skill equilibrium economy; Idaho, Montana, Utah, and Wyoming, to varying degrees, have not. In particular, we posit that Idaho has a low-skill, low-wage problem. This implies that wages are not uniformly low across all Idaho sectors relative to the U.S. Rather, we would expect to accept the hypothesis that wages in matching low-wage sectors of Idaho and the U.S. are not significantly different. In addition, we expect to reject the hypothesis that the average wages in the same high-wage sectors of Idaho and the U.S. are not significantly different.

\section{MEASURES OF WAGE AND EMPLOYMENT GROWTH RATE}

Our goal is to test the R-S "low-skill equilibrium trap" hypothesis. We do so by isolating the Idaho sectors responsible for the changes in the growth of wages and employment, primarily by using the change in growth of wage expenditures. By grouping Idaho sectors by differences in wage and employment growth rates over time and across regions, we can identify the Idaho sectors responsible for the wage gap as well as test for significant differences.

Consider that the average wage per job for a region $(\bar{W})$ is a function of the average wage per job in each sector $\left(\bar{W}_{i}\right)$ of the region's economy and technology-related effects $(\mu)$ (Diewart, 1976, 1993). Assume this wage cost function is convex, twice differentiable, linearly homogeneous and has constant elasticity of substitution (CES) between skilled and less-skilled labor. It is also subject to sector bias and to discrete shifts over time from technological change.

The notation used is as follows. $W$ is wage expenditure (payroll). $N$ is employment (jobs). $\bar{W}(=W / N)$ is average wage per job (wage). $\mu$ is the technology variable. The subscript $i$ denotes sector $i(i=1 \ldots n)$. Subscripts 1 and 0 - for now-refer either to generic changes over time $(T)$ or across regions $(R)$. Later, we will expand this generic subscript notation to include both intertemporal change across subsequent time $\left(T_{1}=2009\right)$ and initial time $\left(T_{0}=2001\right)$ periods and interregional change between the focus region $\left(R_{1}=\mathrm{Idaho}\right)$ and comparison region $\left(R_{0}=\mathrm{U} . \mathrm{S}\right.$.).

A second-order Taylor-series expansion of the wage cost function, $\bar{W}_{1}=f\left(\bar{W}_{i 1}, \mu_{1}\right)$, around point $\bar{W}_{0}$ results in a set of three indices that decompose the rate of growth in overall average wages, $\ln \left(\bar{W}_{1} / \bar{W}_{0}\right)$, into three effects: substitution, sector bias, and technology-related residual as shown in Equation (1):

$$
\ln \left(\frac{\bar{W}_{1}}{\bar{W}_{0}}\right)=\sum_{i} \frac{1}{2}\left(\frac{W_{i 1}}{W_{1}}+\frac{W_{i 0}}{W_{0}}\right) \ln \left(\frac{\bar{W}_{i 1}}{\bar{W}_{i 0}}\right)+\sum_{i}\left(\frac{W_{i 1}}{W_{1}}-\frac{W_{i 0}}{W_{0}}\right) \ln \left(\frac{\bar{W}_{i 1}}{\bar{W}_{i 0}}\right)+\frac{1}{2}\left(S_{u_{1}}+S_{u_{0}}\right) \ln \left(\frac{\mu_{1}}{\mu_{0}}\right) .
$$

For a given technology, the substitution effect reflects the change in the combination of skilled and less-skilled labor from the change in wages. A Tornquist wage index of the substitution effect $\sum_{i} 0.5\left[\left(W_{i 1} / W_{1}\right)+\left(W_{i 0} / W_{0}\right)\right] \ln \left(\bar{W}_{i 1} / \bar{W}_{i 0}\right)$ can be interpreted as a comparison at two points in time in terms of the minimum amount a sector's wages in the initial period could be inflated and still produce at the cost of the subsequent period using the initial period's technology (Caves, Christensen, and Diewart, 1982). The above definition reflects one of two Malmquist index 
interpretations. The other is a comparison in terms of the maximum amount a sector's wages in the subsequent period could be deflated and still produce at the cost of the initial period with the subsequent period's technology. Actually, a Tornquist wage index is the geometric mean of these two Malmquist wage indices.

For a new technology, sector bias $\sum_{i}\left[\left(W_{i 1} / W_{1}\right)-\left(W_{i 0} / W_{0}\right)\right] \ln \left(\bar{W}_{i 1} / \bar{W}_{i 0}\right)$ isolates the effect on wages from a change in the skill intensity needed to implement the technology similar to factor bias. ${ }^{3}$ Sector bias can be viewed as the effect of skill premium on wages from technological change within sectors with changing degrees of specialization (Haskel and Slaughter, 1998). Sector bias embodies the idea that the introduction of new technology in a sector affects the wages of skilled labor more positively than of unskilled labor (Nahuis, 2003).

For example, Finegold and Soskice (1988) have shown for the U.S. that each percentage shift in the labor force from unskilled to skilled raises productivity by 2.0 percent. Mathematically, sector bias represents the interaction between technological change and substitution for each sector. Graphically, sector bias appears as a nonparallel shift in the isoquants of a cost function with the introduction of new technology. Sector bias is defined here as part of the change in a sector's competitive advantage.

The technology-related residual, $0.5\left(S_{u_{1}}+S_{u_{0}}\right) \ln \left(\mu_{1} / \mu_{0}\right)$, equals Hick's neutral technological change omitting the sector bias. Therefore, Hick's neutral technological change for the wage cost function $\left(\tau_{\mu}\right)$ is derived either as the sum of the technology-related residual and sector bias or the difference between actual growth in wages and the substitution effect. These relationships are described in more detail below after we introduce the CES production function for employment.

From duality theory, we know that a wage cost function has a dual production function in terms of employment, which we now consider. Let overall employment in the economy $(N)$ be a function of the employment in each sector $\left(N_{i}\right)$ and a technology-related effect (U), (Diewert, 1976, 1993). A second-order Taylor-series expansion of the employment function $\left(N_{1}=f\left(N_{i 1}, v_{1}\right)\right)$ around point $\left(N_{0}\right)$ results in another set of three CES indices that decompose the overall growth in employment (see Equation (2)).

$$
\ln \left(\frac{N_{1}}{N_{0}}\right)=\sum_{i} \frac{1}{2}\left(\frac{W_{i 1}}{W_{1}}+\frac{W_{i 0}}{W_{0}}\right) \ln \left(\frac{N_{i 1}}{N_{i 0}}\right)+\sum_{i}\left(\frac{W_{i 1}}{W_{1}}-\frac{W_{i 0}}{W_{0}}\right) \ln \left(\frac{N_{i 1}}{N_{i 0}}\right)+\frac{1}{2}\left(S_{v_{1}}+S_{v_{0}}\right) \ln \left(\frac{v_{1}}{v_{0}}\right) .
$$

Tornquist wage and employment indices $-\sum_{i} 0.5\left[\left(W_{i 1} / W_{1}\right)+\left(W_{i 0} / W_{0}\right)\right] \ln \left(\bar{W}_{i 1} / \bar{W}_{i 0}\right)$ and $\sum_{i} 0.5\left[\left(W_{i 1} / W_{1}\right)+\left(W_{i 0} / W_{0}\right)\right] \ln \left(N_{i 1} / N_{i 0}\right)$, respectively-measure the substitution effects in wages and employment independent of the changes in technology including sector bias. Interestingly, the sum of these two substitution effect indices in natural log form very closely approximates overall payroll growth. Because the wage index is derived from a cost function while the employment index is derived from a production function, their sum in natural logs is an approximation, albeit a very good one according to Diewert (1993). Therefore, in this study, the index of the employment

\footnotetext{
${ }^{3}$ Factor bias represents a change in the ratio of unskilled to skilled labor in a cost function caused by the new technology.
} 
substitution effect is derived as the difference between the actual growth in wage expenditures and the index of the wage substitution effect as shown in Equation (3):

$$
\sum_{i} \frac{1}{2}\left(\frac{W_{i 1}}{W_{1}}+\frac{W_{i 0}}{W_{0}}\right) \ln \left(\frac{N_{i 1}}{N_{i 0}}\right)=\ln \left(\frac{\bar{W}_{1} N_{1}}{\bar{W}_{0} N_{0}}\right)-\sum_{i} \frac{1}{2}\left(\frac{W_{i 1}}{W_{1}}+\frac{W_{i 0}}{W_{0}}\right) \ln \left(\frac{\bar{W}_{i 1}}{\bar{W}_{i 0}}\right) .
$$

We now have Tornquist wage and employment substitution-effect indices that will pass a "weak reversibility test" in which the sum of the components equals the whole.

From Equations (1) through (3), we can deduce the Hick's neutral technological change. We know from Equation (3) that the sum of sector bias through wages and the technologyrelated residual in Equation (1) must cancel that for employment in Equation (2).

$$
\begin{aligned}
\sum_{i}\left(\frac{W_{i 1}}{W_{1}}-\frac{W_{i 0}}{W_{0}}\right)\left(\ln \left(\frac{\bar{W}_{i 1}}{\bar{W}_{i 0}}\right)\right)+\frac{1}{2}\left(S_{u_{1}}+S_{u_{0}}\right) \ln \left(\frac{\mu_{1}}{\mu_{0}}\right)+ \\
\sum_{i}\left(\left(\frac{W_{i 1}}{W_{1}}-\frac{W_{i 0}}{W_{0}}\right)\left(\ln \left(\frac{N_{i 1}}{N_{i 0}}\right)\right)+\frac{1}{2}\left(S_{v_{1}}+S_{v_{0}}\right) \ln \left(\frac{v_{1}}{v_{0}}\right)\right)=0
\end{aligned}
$$

If we let

$$
\tau_{u}=\sum_{i}\left(\frac{W_{i 1}}{W_{1}}-\frac{W_{i 0}}{W_{0}}\right)\left(\ln \left(\frac{\bar{W}_{i 1}}{\bar{W}_{i 0}}\right)\right)+\frac{1}{2}\left(S_{u_{1}}+S_{u_{0}}\right) \ln \left(\frac{\mu_{1}}{\mu_{0}}\right)
$$

and

$$
\tau_{v}=\sum_{i}\left(\frac{W_{i 1}}{W_{1}}-\frac{W_{i 0}}{W_{0}}\right)\left(\ln \left(\frac{N_{i 1}}{N_{i 0}}\right)\right)+\frac{1}{2}\left(S_{v_{1}}+S_{v_{0}}\right) \ln \left(\frac{v_{1}}{v_{0}}\right)
$$

then it follows from Equation (4) that

$$
\tau_{u}=-\tau_{v}
$$

Equation (5) shows that the sum of sector bias and the residual associated with technological change obtained by using either a unit cost $\left(\tau_{\mathrm{u}}\right)$ or production function $\left(\tau_{\mathrm{v}}\right)$, results in measures of Hick's neutral technological change $(\tau)$ that are equal in magnitude and opposite in direction (Diewert, 1993). $\tau_{\mathrm{u}}$ can be interpreted as the reduced growth in wages in the initial period if technology were unchanging and equal to the subsequent period's level. $\tau_{\mathrm{v}}$ refers to the rate of labor saved in the initial period using the subsequent period's technology.

To repeat, our goal is to isolate the individual sectors responsible for the growing wage gap in the focus region (Idaho). To this end, observe that the derivatives of Equations (1) and (2) with respect to the sectors' change in wages and jobs, respectively, are equal. We posit that the derivatives of these CES equations configured for intertemporal and interregional change can be used to reveal the sectors in the focus region with greatest (and least) impact on the rate of overall wage and employment growth. Changes in wage and job growth in these sectors would have more influence on overall wage and job growth in Idaho compared to the U.S. as well as over time. The logic of our assertion is as follows. 
Expanding the subscript notation in Equation (1) to include the subscripts for both region $(R)$ and time $(T)$ configured to measure growth in wages over time, the intertemporal wage function for region $R_{1}$ is:

$$
\begin{array}{r}
\ln \left(\frac{\bar{W}_{R_{1} T_{1}}}{\bar{W}_{R_{1} T_{0}}}\right)=\sum_{i} \frac{1}{2}\left(\frac{W_{i R_{1} T_{1}}}{W_{R_{1} T_{1}}}+\frac{W_{i R_{1} T_{0}}}{W_{R_{1} T_{0}}}\right) \ln \left(\frac{\bar{W}_{i R_{1} T_{1}}}{\bar{W}_{i R_{1} T_{0}}}\right)+\sum_{i}\left(\frac{W_{i R_{1} T_{1}}}{W_{R_{1} T_{1}}}-\frac{W_{i R_{1} T_{0}}}{W_{R_{1} T_{0}}}\right) \ln \left(\frac{\bar{W}_{i R_{1} T_{1}}}{\bar{W}_{i R_{1} T_{0}}}\right) \\
+\frac{1}{2}\left(S_{u_{R_{1} T_{1}}}+S_{u_{R_{1} T_{0}}}\right) \ln \left(\frac{\mu_{R_{1} T_{1}}}{\mu_{R_{1} T_{0}}}\right)
\end{array}
$$

Taking the derivative of Equation (6) with respect to the growth in wages for sector $i$ in region 1 over time between $\left(T_{1}\right)$ and $\left(T_{0}\right)$ and simplifying results in

$$
\begin{aligned}
\varepsilon_{R_{1} T} & =\partial \ln \left(\frac{\bar{W}_{R_{1} T_{1}}}{\bar{W}_{R_{1} T_{0}}}\right) / \partial \ln \left(\frac{\bar{W}_{i R_{1} T_{1}}}{\bar{W}_{i R_{1} T_{0}}}\right)=\frac{1}{2}\left(\frac{W_{i R_{1} T_{1}}}{W_{R_{1} T_{1}}}+\frac{W_{i R_{1} T_{0}}}{W_{R_{1} T_{0}}}\right)+\left(\frac{W_{i R_{1} T_{0}}}{W_{R_{1} T_{1}}}-\frac{W_{i R_{1} T_{0}}}{W_{R_{1} T_{0}}}\right) \\
& =\frac{3}{2} \frac{W_{i R_{1} T_{1}}}{W_{R_{1} T_{1}}}-\frac{1}{2} \frac{W_{i R_{1} T_{0}}}{W_{R_{1} T_{0}}} .
\end{aligned}
$$

The result is a set of $n$ intertemporal wage elasticities $\varepsilon_{R_{1} T}$ interpreted as the extent to which the rate of wage growth in each sector influences the overall rate of wage growth in region $\mathrm{R} 1$. The intertemporal elasticity from sector $i$ over time equals the sum of the average change in the wage expenditure shares (a level equal to the weight of the substitution effect) and the difference in expenditure shares (a change equal to the weight of the sector bias). Similarly, a set of intertemporal wage elasticities for each sector exists in the comparison region $0, \varepsilon_{R_{0} T}$.

Ironically, the difference between the two sets of intertemporal elasticities $\varepsilon_{R_{1} T}$ and $\varepsilon_{R_{0} T}$ enables a set of interregional comparisons, $\varepsilon_{\left(R_{1}-R_{0}\right) T}=\Delta \varepsilon_{T}$, for the precise influence that a change in the rate of wage growth in the sectors have had on the relative rates of growth in overall wages. The difference in the intertemporal elasticities of wage growth rates $\left(\Delta \varepsilon_{T}\right)$ is:

$$
\Delta \varepsilon_{T}=\frac{3}{2} \frac{W_{i R_{1} T_{1}}}{W_{R_{1} T_{1}}}-\frac{1}{2} \frac{W_{i R_{1} T_{0}}}{W_{R_{1} T_{0}}}-\left(\frac{3}{2} \frac{W_{i R_{0} T_{1}}}{W_{R_{0} T_{1}}}-\frac{1}{2} \frac{W_{i R_{0} T_{0}}}{W_{R_{0} T_{0}}}\right) .
$$

This difference in intertemporal wage elasticities in Equation (8) provides an interregional comparison of the change in wage expenditures in sector $i$ across the focus and comparison regions. We can use this interregional change in sector influence to identify the sectors in which wage and job growth most affected the overall growth in average wage in Idaho compared to the U.S.

Alternatively, we expand the notation in Equation (1) configured to measure growth in wages across regions at both $T_{1}$ and $\mathrm{T}_{0}$. The interregional wage function for time $T_{1}$ is: 


$$
\begin{aligned}
\ln \left(\frac{\bar{W}_{R_{1} T_{1}}}{\bar{W}_{R_{0} T_{1}}}\right) & =\sum_{i} \frac{1}{2}\left(\frac{W_{i R_{1} T_{1}}}{W_{R_{1} T_{1}}}+\frac{W_{i R_{0} T_{1}}}{W_{R_{0} T_{1}}}\right) \ln \left(\frac{\bar{W}_{i R_{1} T_{1}}}{\bar{W}_{i R_{0} T_{1}}}\right)+\sum_{i}\left(\frac{W_{i R_{1} T_{1}}}{W_{R_{1} T_{1}}}-\frac{W_{i R_{0} T_{1}}}{W_{R_{0} T_{1}}}\right) \ln \left(\frac{\bar{W}_{i R_{1} T_{1}}}{\bar{W}_{i R_{0} T_{1}}}\right) \\
+ & \frac{1}{2}\left(S_{u_{R_{1} T_{1}}}+S_{u_{R_{0} T_{1}}}\right) \ln \left(\frac{\mu_{R_{1} T_{1}}}{\mu_{R_{0} T_{1}}}\right)
\end{aligned}
$$

In this case, we take the derivative of Equation (9) first with respect to the growth in wages in sector $i$ across regions $R_{1}$ and $R_{0}$ at time $T_{1}$ and also at time $T_{0}$. The result is two sets of interregional elasticities $\varepsilon_{R T_{1}}$ and $\varepsilon_{R T_{0}}$ for each sector. Again ironically, the difference between interregional elasticities $\varepsilon_{R T_{1}}$ and $\varepsilon_{R T_{0}}$ results in the intertemporal change in sector $i$ 's wage expenditures $\varepsilon_{R\left(T_{1}-T_{0}\right)}=\Delta \varepsilon_{R}$ in the focus region between the two points in time:

$$
\Delta \varepsilon_{R}=\frac{3}{2} \frac{W_{i R_{1} T_{1}}}{W_{R_{1} T_{1}}}-\frac{1}{2} \frac{W_{i R_{1} T_{1}}}{W_{R_{1} T_{1}}}-\left(\frac{3}{2} \frac{W_{i R_{1} T_{0}}}{W_{R_{1} T_{0}}}-\frac{1}{2} \frac{W_{i R_{0} T_{0}}}{W_{R_{0} T_{0}}}\right) .
$$

Equations (8) and (10) can be interpreted in terms of either wages or employment because the derivative of Equation (1) with respect to the rate of growth in wages is the same as that for Equation (2) with respect to the rate of growth in employment.

We can use Equations (8) and (10) to identify the source of the wage gap in Idaho relative to the U.S. Because there is no a priori constraint on the direction of either $\Delta \varepsilon_{\mathrm{T}}$ or $\Delta \varepsilon_{\mathrm{R}}$, the difference in elasticities can be used to categorize each sector in the focus region into one of four groups as follows.

Group A: $\Delta \varepsilon_{T}$ and $\Delta \varepsilon_{R}$ both positive,

Group B: $\Delta \varepsilon_{T}$ positive and $\Delta \varepsilon_{R}$ negative,

Group C: $\Delta \varepsilon_{T}$ negative and $\Delta \varepsilon_{R}$ positive, and

Group D: $\Delta \varepsilon_{T}$ and $\Delta \varepsilon_{R}$ both negative.

In the focus region, Group A sectors' rates of wage and employment growth are greater over time and relative to the comparison region. (See Table 2.) Group B sectors have a lower rate of growth over time but a higher rate of growth than the comparison region. Group $\mathrm{C}$ sectors have a higher rate of growth over time but a lower rate of growth than the comparison region. Group D sectors have a lower rate of growth in wages and employment both over time and relative to the comparison region. To close a wage gap in the focus region, we should observe above-average wage sectors in Groups A and B and below-average wage sectors Groups C and D. If this is the case, or if wages among the groups are not significantly different, we can conclude the focus region is pursuing a high-skill equilibrium development strategy. However, if the opposite is the case, and the wages in Groups A and B are significantly lower than those in Groups C and D, we can conclude that the focus region has fallen into a low-skill equilibrium trap. This is our critical test.

In the process of testing the R-S low-skill equilibrium trap hypothesis, we can also test the assumption that relative wage inequality and relative wage growth are directly related. We expect to observe that overall wage inequality decreases in a region caught in a low-skill equilibrium trap as low-wage employment substitutes for high-wage employment over time. Conceição and 
TABLE 2. Taxonomy of Focus Region Sectors by the Difference in Interregional and Intertemporal Wage and Employment Elasticities

\begin{tabular}{|c|c|c|}
\hline & $\varepsilon_{R T_{1}} \geq \varepsilon_{R T_{0}}$ & $\varepsilon_{R T_{1}}<\varepsilon_{R T_{0}}$ \\
\hline$\varepsilon_{R_{1} T} \geq \varepsilon_{R_{0} T}$ & $\begin{array}{c}\frac{\text { Group A }}{\varepsilon_{R T_{1}} \geq \varepsilon_{R T_{0}}} \\
\varepsilon_{R_{1} T} \geq \varepsilon_{R_{0} T}\end{array}$ & $\begin{array}{c}\frac{\text { Group B }}{\varepsilon_{R T_{1}}<\varepsilon_{R T_{0}}} \\
\varepsilon_{R_{1} T} \geq \varepsilon_{R_{0} T}\end{array}$ \\
\hline$\varepsilon_{R_{1} T}<\varepsilon_{R_{0} T}$ & $\begin{array}{c}\frac{\text { Group } C}{\varepsilon_{R T_{1}} \geq \varepsilon_{R T_{0}}} \\
\varepsilon_{R_{1} T}<\varepsilon_{R_{0} T}\end{array}$ & $\begin{array}{c}\frac{\text { Group D }}{\varepsilon_{R T_{1}}<\varepsilon_{R T_{0}}} \\
\varepsilon_{R_{1} T}<\varepsilon_{R_{0} T} T\end{array}$ \\
\hline
\end{tabular}

Galbraith (2000) have developed a partial-Theil inequality index using wage and employment data. The partial-Theil $\left(\dot{T}^{\prime}\right)$ inequality indices provide a proxy measure of income inequality from changes in wages and employment. As with the difference in wage elasticity measures, the difference in partial Theil inequality indices can be configured to reflect both intertemporal and interregional changes with their accompanying ironies of interpretation.

The intertemporal partial-Theil between-sector inequality index in region $R_{1}$ is:

$$
\begin{aligned}
\dot{T}_{R_{1} T}^{\prime}= & \sum_{i}\left(\frac{\bar{W}_{i R_{1} T_{1}} N_{i R 1 T_{0}}}{\bar{W}_{R_{1} T_{1}} N_{R_{1} T_{0}}} \ln \left(\frac{\bar{W}_{i R_{1} T_{1}}}{\bar{W}_{R_{1} T_{1}}}\right) \ln \left(\frac{N_{i R_{1} T_{1}} / N_{R_{1} T_{1}}}{N_{i R_{1} T_{0}} / N_{R_{1} T_{0}}}\right)\right) \\
& +\sum_{i}\left(\frac{\bar{W}_{i R_{1} T_{0}} N_{i R_{1} T_{1}}}{\bar{W}_{R_{1} T_{0}} N_{R_{1} T_{1}}}\left(\ln \frac{\bar{W}_{i R_{1} T_{1}}}{\bar{W}_{R_{1} T_{1}}}+1\right) \ln \left(\frac{\bar{W}_{i R_{1} T_{1}} / \bar{W}_{R_{1} T_{1}}}{\bar{W}_{i R_{1} T_{0}} / \bar{W}_{R_{1} T_{0}}}\right)\right) .
\end{aligned}
$$

There is a similar intertemporal partial Theil for region $R_{0}$, which can be denoted $\dot{T}_{R_{0} T}^{\prime}$. The difference between these intertemporal Theil indices $\left(\Delta T h_{T}=\dot{T}_{\left(R_{1}-R_{0}\right) T}^{\prime}\right)$ shows the relative change in inequality across the two regions caused by each sector:

$$
\Delta T h_{T}=\dot{T}_{R_{1} T}^{\prime}-\dot{T}_{R_{0} T}^{\prime}
$$

In time $T_{1}$ the interregional partial-Theil between-sector inequality index is:

$$
\begin{aligned}
\dot{T}_{R T_{1}}^{\prime}= & \sum_{i}\left(\frac{\bar{W}_{i R_{1} T_{1}} N_{i R_{0} T_{1}}}{\bar{W}_{R_{1} T_{1}} N_{R_{0} T_{1}}} \ln \left(\frac{\bar{W}_{i R_{1} T_{1}}}{\bar{W}_{R_{1} T_{1}}}\right) \ln \left(\frac{N_{i R_{1} T_{1}} / N_{R_{1} T_{1}}}{N_{i R_{0} T_{1}} / N_{R_{0} T_{1}}}\right)\right) \\
& +\sum_{i}\left(\frac{\bar{W}_{i R_{0} T_{1}} N_{i R_{1} T_{1}}}{\bar{W}_{R_{0} T_{1}} N_{R_{1} T_{1}}}\left(\ln \frac{\bar{W}_{i R_{1} T_{1}}}{\bar{W}_{R_{1} T_{1}}}+1\right) \ln \left(\frac{\bar{W}_{i R_{1} T_{1}} / \bar{W}_{R_{1} T_{1}}}{\bar{W}_{i R_{0} T_{1}} / \bar{W}_{R_{0} T_{1}}}\right)\right) .
\end{aligned}
$$


Naturally, there is a similar interregional partial Theil for time $T_{0}$ labeled $\dot{T}_{R T_{0}}^{\prime}$. The difference between these interregional Theil indices, $\Delta T h_{R}=\dot{T}_{R\left(T_{1}-T_{0}\right)}^{\prime}$, shows the relative change in inequality across time $T 1$ and $T_{0}$ caused by each sector.

$$
\Delta T h_{R}=\dot{T}_{R T_{1}}^{\prime}-\dot{T}_{R T_{0}}^{\prime}
$$

Deller et al. (2001) state that the relationship between income equality and income growth is "unclear," at least in rural counties of the U.S. We help clarify this problem by testing R-S's theory in light of the partial-Theil inequality index. We posit that, relative to the U.S., wage inequality will decrease in a region caught in a low-skill equilibrium trap as low-wage employment substitutes for high-wage employment over time. We modify the previous critical test of the lowskill equilibrium trap as follows. If wages in Group A and B as defined by wage elasticities described above are significantly lower than those in Groups $\mathrm{C}$ and D and if we observe a relative decrease in overall wage inequality, then we cannot reject the conclusion that the focus region has fallen into a low-skill equilibrium trap.

\section{DATA}

The data used in this study include the wage expenditure and employment data disclosed at the three-digit level for North American Industrial Classification System (NAICS) sectors for the years 2001 and 2009 for Idaho and the U.S. (U.S. Bureau of Economic Analysis, 2009b). Published sources do not disclose data for 12 Idaho industries at the three-digit NAICS level, ${ }^{4}$ so we limit our analysis to 81 sectors.

The wage expenditure data (the SA07 series) are of wage and salary disbursements by industry measured in thousands of dollars. Wage disbursements in 2001 and 2009 dollars are in nominal dollars. Comparisons of growth rates across regions in the same period need no inflation adjustment. Comparison across periods could benefit from inflation adjustments, but comparisons of rates of change across two regions over time, as performed here, cancels any inflation adjustments. Like the SA07 series data, the employment data (the SA27 series) are based on the Quarterly Census of Employment and Wages, which collects data for the purpose of unemployment insurance coverage by place of work and give equal weight to full- and part-time jobs. ${ }^{5}$ This series does not include proprietors, unpaid family labor, or volunteers.

Prior wage studies have tended to use Current Population Survey (CPS) data to estimate associations of worker characteristics and wage differences by occupation (Bluestone and Harrison, 1988; Bound and Johnson, 1992; DiNardo, Fortin, and Lemieux, 1996; Juhn, Murphy, and Pierce, 1993; Krueger and Summers, 1988). Indeed, Bound and Johnson (1992) and DiNardo, Fortin, and Lemieux (1996) focus on the effects of such things as gender, race, and education on

TABLE 3. Payroll, Jobs, and Wages for Idaho and the U.S.: 2001 and 2009 (nominal \$)

\footnotetext{
${ }^{4}$ The 12 nondisclosed or empty sectors in Idaho at the three digit NAICS level include: oil and gas extraction, support activities for mining, motor vehicles - bodies, trailers and parts manufacturing, other transportation equipment manufacturing, textile mills, petroleum and coal products manufacturing, rail transportation, water transportation, pipeline transportation, internet publishing and broadcasting, monetary authorities - central bank, and funds - trusts - other financial vehicles.

5 "The lack of a full-time equivalent (FTE) measure limits the usefulness of the average earnings measure that can be calculated from the BEA county employment and earnings estimates. Average earnings reflects the extent of part-time employment in the given area and industry, as well as more basic factors such as hourly wage rates" (U.S. Bureau of Economic Analysis). We recognize this limitation of the wage and salary employment data, and, consequently, the results below should be interpreted with this bias in mind.
} 


\begin{tabular}{|c|c|c|c|c|}
\hline $\begin{array}{l}\text { Region } \\
\text { Category }\end{array}$ & $\begin{array}{c}\text { measurement } \\
\text { unit }\end{array}$ & 2001 & 2009 & change \\
\hline \multicolumn{5}{|l|}{ Idaho } \\
\hline Payroll & (\$ mil.) & 16,991 & 22,917 & 29.9 \\
\hline Jobs & $(\#)$ & 610,837 & 652,381 & 6.6 \\
\hline Wage/job & (\$) & 27,816 & 35,129 & 23.3 \\
\hline \multicolumn{5}{|c|}{ United States } \\
\hline Payroll & (\$ mil.) & $4,948,357$ & $6,265,405$ & 23.6 \\
\hline Jobs & (\#) & $137,322,000$ & $136,731,000$ & -0.4 \\
\hline Wage/job & (\$) & 36,035 & 45,823 & 24.0 \\
\hline \multicolumn{5}{|l|}{ Difference } \\
\hline Payroll & (\$ mil.) & $-5,020$ & $-6,977$ & 32.9 \\
\hline Jobs & $(\#)$ & & & \\
\hline Wage/job & $(\$)$ & $-8,219$ & $-10,694$ & 26.3 \\
\hline \multicolumn{5}{|c|}{ Growth: ID to U.S. } \\
\hline Payroll & $\%)$ & -567.4 & -561.1 & 6.3 \\
\hline Jobs & $(\%)$ & -541.5 & -534.5 & 7.0 \\
\hline Wage/job & $(\%)$ & -25.9 & -26.6 & -0.7 \\
\hline
\end{tabular}

wages by occupation with little or no regard to wages and employment by sector. Due to self-reporting nature of the CPS, Conceição and Galbraith (2000) have noted that these data have less information content compared to the wage and employment data by industrial classification. Kim (1998, p.680) concludes that "[a]n analysis of the causes of the differences in inter-industry earnings ...[is needed for] a more complete understanding of American economic development."

\section{SOURCES OF WAGE DIVERGENCE}

Between 2001 and 2009, the difference between the average wage per job in Idaho and the U.S. expanded from $\$ 8,200$ to $\$ 10,700$; the wage gap grew by 26 percent. In 2009 , this $\$ 2,500$ per job erosion in average wages cost the 650,000 workers of Idaho an additional $\$ 1.6$ billion in lost wages, ceteris paribus. See Table 3 . We begin by testing whether the wage gap between Idaho and the U.S. is statistically significant with the null hypothesis being that there is no difference in average wage per job among the 81 sectors between Idaho and the U.S. in 2009.

Using a one-tailed $t$-test of two samples with unequal variance, this null hypothesis is rejected $(n=135, \alpha=.025, t=3.81, p=0.00)$. See Appendix Table A1. As expected, the U.S. average wage across sectors is significantly higher in the U.S. than in Idaho. What sectors in particular are responsible for this wage gap? Do these sectors represent a pattern, such as that predicted by what $\mathrm{R}-\mathrm{S}$ theory describes as a low-skill equilibrium trap?

The aggregate intertemporal and interregional CES indices that decompose the actual overall growth for wages and employment into the substitution effect, sector bias, and Hick's neutral technological change are presented in Table 4. Nahuis (2003, pp. 47-48) explains sector biased technical change as "the common-sense idea that new technology mostly replaces unskilled 


\section{TABLE 4. Tornquist Wage and Employment Indices for Idaho and U.S. in 2001 and 2009, (nominal \$)}

\begin{tabular}{|c|c|c|c|c|c|c|c|c|c|}
\hline $2009 / 2001$ & $\begin{array}{c}\text { Idaho } \\
\text { Payroll } \\
(\%)\end{array}$ & $\begin{array}{c}\text { U.S. } \\
\text { Payroll } \\
(\%)\end{array}$ & $\begin{array}{c}\text { Payroll } \\
\text { Diff } \\
(\%)\end{array}$ & $\begin{array}{c}\text { Idaho } \\
\text { Jobs } \\
(\%) \\
\end{array}$ & $\begin{array}{c}\text { U.S. } \\
\text { Jobs } \\
(\%)\end{array}$ & $\begin{array}{l}\text { Jobs } \\
\text { Diff } \\
(\%)\end{array}$ & $\begin{array}{c}\text { Idaho } \\
\text { Wage } \\
(\%)\end{array}$ & $\begin{array}{c}\text { U.S. } \\
\text { Wage } \\
(\%)\end{array}$ & $\begin{array}{l}\text { Wage } \\
\text { Diff } \\
(\%)\end{array}$ \\
\hline Observed Growth & 29.94 & 24.12 & 5.82 & 6.55 & 0.10 & 6.45 & 23.39 & 24.02 & -0.63 \\
\hline Substitution Effect & 29.94 & 24.12 & 5.82 & 4.19 & -1.21 & 5.40 & 25.75 & 25.33 & -0.42 \\
\hline Sector Bias & 5.64 & 3.78 & 1.86 & 4.62 & 3.07 & 1.55 & 1.02 & 0.71 & 0.31 \\
\hline Residual & -5.64 & -3.78 & -1.86 & -2.26 & -1.76 & -0.50 & -3.38 & -2.02 & -1.36 \\
\hline $\begin{array}{l}\text { Hick's Neutral Tech. } \\
\text { Change }\end{array}$ & 0.00 & 0.00 & 0.00 & 2.36 & 1.32 & 1.05 & -2.36 & -1.32 & -1.05 \\
\hline Idaho/U.S. & 2009 & 2001 & $\Delta$ & 2009 & 2001 & $\Delta$ & 2009 & 2001 & $\Delta$ \\
\hline Observed Growth & -559.1 & -564.9 & 5.82 & -533.4 & -539.8 & 6.45 & -25.8 & -25.1 & -0.63 \\
\hline Substitution Effect & -559.1 & -564.9 & 5.82 & -534.6 & -541.1 & 6.52 & -24.5 & -23.8 & -0.71 \\
\hline Sector Bias & 21.4 & 28.5 & -7.04 & 15.5 & 23.3 & -7.74 & 5.9 & 5.2 & 0.70 \\
\hline Residual & -21.4 & -28.5 & 7.04 & -14.3 & -22.0 & 7.67 & -7.1 & -6.5 & -0.63 \\
\hline $\begin{array}{l}\text { Hick's Neutral Tech. } \\
\text { Change }\end{array}$ & 0.00 & 0.00 & 0.00 & 1.24 & 1.32 & -0.08 & -1.2 & -1.3 & 0.08 \\
\hline
\end{tabular}

workers." Positive sector bias is typically associated with the effect of an increased demand for high-skill workers on wages and employment caused by technical change in sectors with increasing specialization (Card and DiNardo, 2002). ${ }^{6}$ Alternatively, the low-skill equilibrium trap theory suggests that positive sector bias is more likely to be present in low-skill/low-wage sectors because of an institutional bias in favor of these sectors. The sum of the difference in intertemporal sector bias for wages ( 0.31 percent) and employment ( 1.55 percent $)$ across Idaho and the U.S. is 1.86 percent. These numbers suggest that the total difference in sector bias between Idaho and the U.S. can be assigned to the differential growth in wages and employment as 17 and 83 percent, respectively. Given that Idaho's wage gap is growing, this result suggests the state not only has a low-wage problem, but a serious low-wage job problem.

The low-skill equilibrium trap theory predicts a lack of growth in high-skill/high-wage sectors. Hypotheses generated from this theory are tested by isolating the sectors that are most responsible for the growing wage gap between Idaho and the U.S. To determine the Idaho sectors that grew more or less than the U.S. average and over time, we sorted and compared the difference in intertemporal and interregional wage elasticities for each sector as follows. ${ }^{7}$ First, sort the sectors into two categories based on the sign of the difference in intertemporal elasticities $\left(\Delta \varepsilon_{\mathrm{T}}\right)$. Next, within each of the two $\left(\Delta \varepsilon_{\mathrm{T}}\right)$ categories, sort the sectors based on sign of the difference in interregional elasticities $\left(\Delta \varepsilon_{R}\right)$. Finally, within each group of sectors (A-D) (see Table 2), the sectors are sorted again by the absolute magnitude of their difference in intertemporal elasticity $\left(\Delta \varepsilon_{\mathrm{T}}\right)$. In addition, the natural resource sectors are grouped together for separate analysis. See Tables 5-10.

\footnotetext{
${ }^{6}$ An example of sector bias is the effect on the wages and employment of high-skill workers with the introduction of the personal computer.

${ }^{7}$ Tornquist indices derived from Tornquist sub-indices for wage and labor by sector — calculated in two steps—are approximately equal to their respective Tornquist indices for the economy calculated in one step (Diewert 1993).
} 
Fick (2008, p. 1-2) argues that the loss of the "comparatively high-paying jobs timber and mining provided" is responsible for the widening wage gap in Idaho.. The six natural resource sectors in descending order of influence on Idaho's rate of growth in overall wages relative to the U.S. are: 1) a tie between mining and wood products manufacturing, 3) a tie between paper manufacturing and forestry \& logging, 5) nonmetallic mineral product manufacturing, and 6) primary metal manufacturing. See Table 6. As a group, natural resource sectors are similar to the sectors in Group B (see Table 8): the influence of the natural resource sectors' rate of growth in wages on Idaho's overall wage growth decreased over time (-1.1 percent) and yet the influence of the rate of growth in wages increased compared to the U.S. (0.6 percent). The difference in the intertemporal Theil index $\left(\Delta T h_{T}\right)$ shows that the wage and employment growth in these sectors has decreased Idaho's wage inequality compared to the U.S. For example, wood product manufacturing is an influential natural resource sector in which, judging by the difference in sector bias, wage growth has slowed (-0.1) and employment growth has increased (0.3) relative to the nation. We test the null hypothesis that there is no difference between U.S. $(\$ 49,456)$ and Idaho $(\$ 45,366)$ average wages per job in these natural resource sectors. Using a one-tailed $t$-test of two samples assuming unequal variances, we cannot reject the null hypothesis $(n=10, \alpha=.025, t=0.64$, $p=0.27$ ). See Appendix Table A1. The natural resource sectors' level of average wages per job in Idaho is not significantly different from the U.S.'s average wages. Given that there is a significant difference among sector wages between Idaho and the U.S., these data show that changes in the natural resource sectors in Idaho cannot be the cause of the state's expanding wage gap compared to the U.S. between 2001 and 2009. If the natural resource sectors were not responsible for the increase in Idaho's wage gap, then which sectors were?

The Idaho Group A and B sectors have increased impact on the state's wage and employment growth rate relative to the U.S. by 12.6 percent. These "Sailing-with-the-Wind Sectors" include, in decreasing order: 1) farm wages, 2) a tie between computer \& electronic product manufacturing and food manufacturing, and 4) a tie between administrative \& support services $^{8}$ and motor vehicle and parts dealers. See Tables 7 and 8. With in Group A, farm wages and administrative and support services are increasing their influence on Idaho's average wage over time. Farm wages in particular and Group A sectors in general are increasing wage inequality between Idaho and the U.S. and over time. As with all sectors in Group B, the computer \& electronic product manufacturing, food manufacturing, and motor vehicle and parts dealers sectors are reducing their influence on overall rate of wage growth over time. Computer \& electronic product manufacturing single-handedly sets the tone for all the sectors in Group B: its sector bias indices show a large decrease in wage growth ( -0.8 percent) and a larger increase in employment growth (1.1 percent) compared to the U.S. See Table 5. In general, sectors in this group are decreasing wage inequality compared to the U.S.'s and over time, primarily because of the decreasing rate of growth in wages affecting the computer \& electronic products manufacturing sector.

\footnotetext{
${ }^{8}$ This is NAICS sector 56, defined as the Administrative and Support and Waste Management and Remediation Services sector comprises establishments performing routine support activities for the day-to-day operations of other organizations. Establishments in many sectors of the economy often undertake these essential activities in-house. The establishments in this sector specialize in one or more of these support activities and provide these services to clients in a variety of industries and, in some cases, to households. Activities performed include office administration, hiring and placing of personnel, document preparation, telephone call centers and similar clerical services, solicitation, collection, security and surveillance services, cleaning, and waste disposal services (http://www.census.gov/cgi-bin/sssd/naics).
} 
TABLE 5. Difference in Intertemporal and Interregional Wage and Employment Elasticities, Sector Bias and Theil Inequality Indices and Average Wage per Job: Idaho Sector Groups

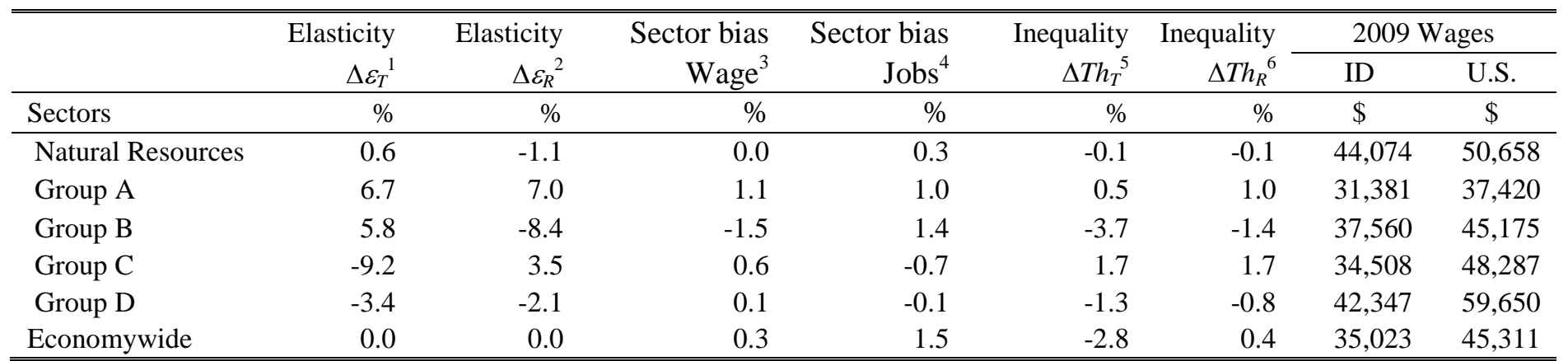

1. $\Delta \varepsilon_{T}=\varepsilon_{R_{T} T}-\varepsilon_{R_{T} T} \geq 0$ : Sector's expenditure share in the focus region (ID) has increased more than in the comparison region (U.S.). Positive differences reveal

that wage and job growth in these sectors would have more influence on the overall wage and job growth in ID than in the U.S.

2. $\Delta \varepsilon_{R}=\varepsilon_{R T_{1}}-\varepsilon_{R T_{0}} \geq 0$ : Sector's expenditure share in the focus region (ID) has increased over time.

3. Sector Bias-Wage: A positive difference in sector bias means the differential growth in wages is greater in Idaho than the U.S.

4. Sector Bias-Jobs: A positive difference in sector bias means the differential growth in employment is greater in Idaho than the U.S.

. $\Delta T h_{T}=\dot{T}_{R_{T} T}^{\prime}-\dot{T}_{R_{0}}^{\prime} \geq 0$ : If positive, the sector's contribution to wage inequality in the focus region (ID) has increased more than in the comparison region (U.S.).

6. $\Delta T h_{R}=\dot{T}_{R T_{1}}^{\prime}-\dot{T}_{R T_{0}}^{\prime} \geq 0$ : If positive, the sector's contribution to wage inequality in the focus region (ID) has increased over time.

TABLE 6. Idaho Natural Resource Sectors: Difference in Intertemporal and Interregional Wage and Employment Elasticities, Sector Bias and Theil Inequality Indices and Average Wage per Job

\begin{tabular}{|c|c|c|c|c|c|c|c|c|c|}
\hline & \multirow{2}{*}{$\begin{array}{l}\text { Natural Resource } \\
\text { (Forestry and Mining related) }\end{array}$} & \multirow[b]{2}{*}{$\Delta \varepsilon_{T}$} & \multirow[b]{2}{*}{$\Delta \varepsilon_{R}$} & \multirow{2}{*}{$\begin{array}{r}\text { Sector bias } \\
\text { Wage }\end{array}$} & \multirow{2}{*}{$\begin{array}{r}\text { Sector bias } \\
\text { Jobs }\end{array}$} & \multirow[b]{2}{*}{$\Delta T h_{T}$} & \multirow[b]{2}{*}{$\Delta T h_{R}$} & \multicolumn{2}{|c|}{2009 Wages } \\
\hline & & & & & & & & ID & U.S. \\
\hline Code & Sector & $\%$ & $\%$ & $\%$ & $\%$ & $\%$ & $\%$ & $\$$ & $\$$ \\
\hline 202 & Mining (except oil and gas) & 0.3 & 0.1 & 0.0 & 0.0 & 0.1 & 0.1 & 57,159 & 64,348 \\
\hline 511 & Wood product manufacturing & 0.3 & -1.0 & -0.1 & 0.3 & -0.2 & -0.3 & 36,422 & 36,349 \\
\hline 537 & Paper manufacturing & 0.1 & -0.1 & 0.0 & -0.1 & 0.0 & 0.1 & 59,671 & 57,244 \\
\hline 101 & Forestry and logging & 0.1 & -0.3 & 0.0 & 0.1 & 0.0 & -0.1 & 38,412 & 35,828 \\
\hline 512 & Nonmetallic mineral product manufacturing & 0.0 & 0.0 & 0.0 & 0.0 & 0.0 & 0.0 & 42,009 & 47,482 \\
\hline 513 & Primary metal manufacturing & -0.1 & 0.2 & 0.1 & -0.1 & 0.1 & 0.1 & 38,524 & 55,486 \\
\hline & Natural resource sectors & 0.6 & -1.1 & 0.0 & 0.3 & -0.1 & -0.1 & 44,074 & 50,658 \\
\hline & Economywide & 0.0 & 0.0 & 0.3 & 1.5 & -2.8 & 0.4 & 35,023 & 45,311 \\
\hline
\end{tabular}

(C) Southern Regional Science Association 2011. 
TABLE 7. Idaho Group A Sectors: Difference in Intertemporal and Interregional Wage and Employment Elasticities, Sector Bias and Theil Inequality Indices and Average Wage per Job

(Ordered by the Rate of Interregional Growth, Highest to Lowest)

\begin{tabular}{|c|c|c|c|c|c|c|c|c|c|}
\hline & \multirow[t]{2}{*}{ Group A Sectors: } & \multicolumn{6}{|c|}{ "Sector bias ${ }^{3} \quad$ Sector bias $^{4}$} & \multicolumn{2}{|c|}{2009 Wages } \\
\hline & & $\Delta \varepsilon_{\mathrm{T}}^{1}$ & $\Delta \varepsilon_{\mathrm{R}}^{2}$ & Wage & Jobs & $\Delta \mathrm{Th}_{\mathrm{T}}{ }^{5}$ & $\Delta \mathrm{Th}_{\mathrm{R}}{ }^{6}$ & ID & U.S. \\
\hline Code & Sector & $\%$ & $\%$ & $\%$ & $\%$ & $\%$ & $\%$ & $\$$ & $\$$ \\
\hline 81 & Farm wage and salary disbursements & 2.8 & 1.0 & 0.5 & -0.1 & 0.8 & 1.1 & 43,514 & 32,260 \\
\hline 1401 & Administrative and support services & 0.7 & 1.2 & 0.3 & 0.1 & -0.1 & -0.1 & 25,580 & 32,743 \\
\hline 804 & Truck transportation & 0.6 & 0.0 & 0.0 & 0.0 & 0.0 & 0.1 & 36,845 & 41,835 \\
\hline 711 & General merchandise stores & 0.5 & 0.2 & 0.0 & 0.0 & 0.0 & 0.0 & 21,428 & 21,607 \\
\hline 103 & Agriculture and forestry support activities & 0.4 & 0.0 & 0.0 & 0.0 & 0.1 & 0.1 & 23,753 & 23,218 \\
\hline 202 & Mining (except oil and gas) & 0.3 & 0.1 & 0.0 & 0.0 & 0.1 & 0.1 & 57,159 & 64,348 \\
\hline 713 & Non-store retailers & 0.3 & 0.4 & 0.1 & 0.1 & 0.1 & 0.1 & 42,617 & 45,071 \\
\hline 1601 & Ambulatory health care services & 0.3 & 1.4 & -0.1 & 0.3 & -0.5 & -0.2 & 42,549 & 54,124 \\
\hline 707 & Gasoline stations & 0.2 & 0.0 & 0.0 & 0.0 & 0.0 & 0.0 & 17,067 & 19,174 \\
\hline 709 & Sporting goods, hobby, book and music stores & 0.2 & 0.1 & 0.0 & 0.0 & 0.0 & 0.0 & 17,985 & 19,088 \\
\hline 712 & Miscellaneous store retailers & 0.2 & 0.0 & 0.0 & 0.0 & 0.0 & 0.0 & 20,721 & 23,200 \\
\hline 1604 & Social assistance & 0.1 & 0.2 & 0.0 & 0.0 & 0.0 & 0.0 & 18,211 & 23,053 \\
\hline 1703 & Amusement, gambling, and recreation & 0.1 & 0.2 & 0.0 & 0.0 & 0.0 & 0.0 & 19,205 & 24,188 \\
\hline 102 & Fishing, hunting, and trapping & 0.0 & 0.0 & 0.0 & 0.0 & 0.0 & 0.0 & 19,889 & 44,500 \\
\hline 535 & Apparel manufacturing & 0.0 & 0.1 & 0.1 & -0.1 & -0.1 & -0.2 & 26,401 & 34,970 \\
\hline 536 & Leather and allied product manufacturing & 0.0 & 0.0 & 0.0 & 0.0 & 0.0 & 0.0 & 28,300 & 36,333 \\
\hline 807 & Scenic and sightseeing transportation & 0.0 & 0.0 & 0.0 & 0.0 & 0.0 & 0.0 & 18,875 & 30,308 \\
\hline 907 & Other information services & 0.0 & 0.2 & 0.0 & 0.2 & 0.0 & -0.1 & 55,470 & 89,985 \\
\hline 1402 & Waste management and remediation services & 0.0 & 0.1 & 0.0 & 0.0 & 0.0 & 0.0 & 40,852 & 51,193 \\
\hline 1602 & Hospitals & 0.0 & 1.6 & 0.1 & 0.4 & 0.2 & 0.2 & 46,964 & 52,968 \\
\hline 1904 & Private households & 0.0 & 0.0 & 0.0 & 0.0 & 0.0 & 0.0 & 10,019 & 13,039 \\
\hline 2002 & Military & 0.0 & 0.3 & -0.1 & 0.0 & 0.0 & 0.0 & 37,382 & 47,011 \\
\hline & Group A sectors & 6.7 & 7.0 & 1.1 & 1.0 & 0.5 & 1.0 & 31,381 & 37,420 \\
\hline & Economywide & 0.0 & 0.0 & 0.3 & 1.5 & -2.8 & 0.4 & 35,023 & 45,311 \\
\hline
\end{tabular}

(C) Southern Regional Science Association 2011. 
TABLE 8. Idaho Group B Sectors: Difference in Intertemporal and Interregional Wage and Employment Elasticities, Sector Bias and Theil Inequality Indices and Average Wage per Job

(Ordered by the Rate of Interregional Growth, Highest to Lowest)

\begin{tabular}{|c|c|c|c|c|c|c|c|c|c|}
\hline & \multirow[t]{2}{*}{ Group B Sectors: } & \multirow[b]{2}{*}{$\Delta \varepsilon_{T}$} & \multirow[b]{2}{*}{$\Delta \varepsilon_{R}$} & \multirow{2}{*}{$\begin{array}{r}\text { Sector bias } \\
\text { Wage }\end{array}$} & \multirow{2}{*}{$\begin{array}{r}\text { Sector bias } \\
\text { Jobs }\end{array}$} & \multirow[b]{2}{*}{$\Delta T h_{T}$} & \multirow[b]{2}{*}{$\Delta T h_{R}$} & \multicolumn{2}{|c|}{2009 Wages } \\
\hline & & & & & & & & ID & U.S. \\
\hline Code & Sector & $\%$ & $\%$ & $\%$ & $\%$ & $\%$ & $\%$ & $\$$ & $\$$ \\
\hline 516 & Computer and electronic product manufacturing & 1.6 & -3.3 & -0.7 & 1.1 & -2.5 & -0.1 & 82,362 & 86,278 \\
\hline 531 & Food manufacturing & 1.6 & -0.4 & -0.1 & 0.0 & 0.1 & 0.1 & 37,465 & 39,869 \\
\hline 701 & Motor vehicle and parts dealers & 0.7 & -0.2 & 0.0 & 0.0 & 0.0 & 0.1 & 36,907 & 40,350 \\
\hline 2011 & State government & 0.5 & -0.7 & -0.1 & 0.0 & -0.1 & -0.1 & 36,011 & 44,922 \\
\hline 402 & Heavy and civil engineering construction & 0.4 & -0.4 & -0.1 & 0.1 & -0.2 & -0.1 & 57,378 & 58,449 \\
\hline 511 & Wood product manufacturing & 0.3 & -1.0 & -0.1 & 0.3 & -0.2 & -0.3 & 36,422 & 36,349 \\
\hline 704 & Building material and garden supply stores & 0.3 & -0.3 & 0.0 & 0.0 & 0.0 & 0.0 & 29,119 & 30,985 \\
\hline 101 & Forestry and logging & 0.1 & -0.3 & 0.0 & 0.1 & 0.0 & -0.1 & 38,412 & 35,828 \\
\hline 403 & Specialty trade contractors & 0.1 & -0.7 & 0.0 & 0.0 & -0.1 & -0.1 & 33,417 & 46,332 \\
\hline 537 & Paper manufacturing & 0.1 & -0.1 & 0.0 & -0.1 & 0.0 & 0.1 & 59,671 & 57,244 \\
\hline 702 & Furniture and home furnishings stores & 0.1 & -0.1 & 0.0 & 0.0 & 0.0 & 0.0 & 28,899 & 30,807 \\
\hline 703 & Electronics and appliance stores & 0.1 & -0.1 & 0.0 & 0.0 & 0.0 & 0.0 & 36,030 & 40,123 \\
\hline 705 & Food and beverage stores & 0.1 & -0.3 & 0.0 & 0.0 & 0.0 & 0.0 & 21,648 & 22,654 \\
\hline 2001 & Federal, civilian & 0.1 & 0.0 & -0.1 & 0.0 & -0.2 & -0.2 & 57,311 & 68,167 \\
\hline 401 & Construction of buildings & 0.0 & -0.5 & 0.0 & 0.0 & -0.2 & -0.3 & 36,896 & 54,222 \\
\hline 1901 & Repair and maintenance & 0.0 & -0.2 & 0.0 & 0.0 & 0.0 & 0.0 & 29,235 & 36,220 \\
\hline \multirow[t]{3}{*}{2012} & Local government & 0.0 & 0.0 & -0.2 & 0.0 & -0.4 & -0.4 & 32,027 & 43,454 \\
\hline & Group B Sectors & 5.8 & -8.4 & -1.5 & 1.4 & -3.7 & -1.4 & 37,560 & 45,175 \\
\hline & Economywide & 0.0 & 0.0 & 0.3 & 1.5 & -2.8 & 0.4 & 35,023 & 45,311 \\
\hline
\end{tabular}


With the possible exception for computer \& electronic product manufacturing, the Sailing-withthe-Wind Sectors could also be described as "low-skill sectors" (Finegold and Soskice, 1988; U.S. Bureau of Labor Statistics, 2009b). In a low-skill equilibrium trap, we would expect to find a positive difference in wage elasticity associated with low-skill/low-wage sectors because theory suggests an institutional bias favors these sectors (Finegold, 1991). ${ }^{9}$ Is Idaho's average wage per job for the low-skill sectors, defined as the sectors in Groups A and B, different from the U.S. average wage per job for these sectors? We test the null hypothesis that there is no difference in average wage per job. ${ }^{10}$ The Sailing-with-the-Wind Sectors are not so much contributing to overall low wages in Idaho because they have lower-than-average wages compared to similar sectors nationwide; rather, they are contributing to the states remarkably low average wages because they are low-wage sectors with a higher-than-average rate of employment growth. Unfortunately, an exception within the Sailing-with-the-Wind Sectors - high-wage computer \& electronic products manufacturing - also has the most rapid rate of wage decline. Based on these results, we cannot reject the possibility that the low-skill equilibrium trap theory applies to Idaho.

Idaho's Group C and D sectors have a diminished influence on the state's overall wage and employment growth rate (-12.6 percent) relative to the U.S. These "Sailing-into-the-Wind Sectors" include, in decreasing order: 1) securities, commodity contracts, \& investments, 2) professional, scientific, \& technical services, 3) management of companies \& enterprises, and 4) a tie between educational services and insurance carriers \& related activities. See Tables 9 and 10. Except for management of companies \& enterprises, these sectors are in Group C. Over time, the Group C sectors have increased their influence on the rate of overall wage growth. Indices of sector bias suggest that the Sailing-into-the-Wind Sectors have increased their rate of growth in wages but have decreased their rate of growth in employment. Most of Group C's employment loss via sector bias appears in the internet service provider, search portals, \& data processing sector $(-0.24$ percent) and in the telecommunications (-0.12 percent) sector. The Theil inequality indices show that these sectors are slightly increasing overall wage inequality when comparing Idaho's economy to that of the U.S. and over time.

The Sailing-into-the-Wind Sectors could also be described as "high-skill sectors" (Finegold and Soskice, 1988; U.S. Bureau of Labor Statistics, 2009b). In a low-skill equilibrium trap, we would expect to find negative differences in wage elasticity associated with high-skill/high-wage sectors because theory suggests an institutional bias against these sectors (Finegold, 1991). ${ }^{11}$ Is Idaho's average wage per job for the high-skill sectors, those in Groups C and D, different from the U.S.? We test the null hypotheses that for each group there is no difference in average wages between Idaho and the U.S. These hypotheses are rejected for both groups using a one-tailed $t$-test, assuming unequal variance: Group $\mathrm{C}$ in which average wages for the U.S. $=\$ 53,864$ and Idaho $=\$ 36,892(n=46, \alpha=025, t=2.91, p=0.00)$, and Group $\mathrm{D}$ in which average wages for the

\footnotetext{
${ }^{9}$ Finegold (1991) lists the institutional preconditions for high-skill equilibrium as policies and programs undertaken by firm managers, labor, and government officials that encourage a long-term perspective, an export focus, and cooperation within a competitive environment as well as improving the education and technology systems.

${ }^{10}$ The comparison between foregone wages for a set of sectors and the state's average wage indicates whether actually achieving the national average wage in these sectors - if they are significantly higher-will contribute to increasing the average wage in the state.

${ }^{11}$ Finegold (1991) lists the institutional preconditions for high-skill equilibrium as policies and programs undertaken by firm managers, labor, and government officials that encourage a long-term perspective, an export focus, and cooperation within a competitive environment as well as improving the education and technology systems.
} 
TABLE 9. Idaho Group C Sectors: Difference in Intertemporal and Interregional Wage and Employment Elasticities, Sector Bias and Theil Inequality Indices and Average Wage per Job

(Ordered by the Rate of Interregional Growth, Lowest to Highest)

\begin{tabular}{|c|c|c|c|c|c|c|c|c|c|}
\hline & \multirow[b]{2}{*}{ Group C Sectors } & \multirow[b]{2}{*}{$\Delta \varepsilon_{T}$} & \multicolumn{2}{|r|}{ Sector bias } & \multicolumn{2}{|l|}{ Sector bias } & \multicolumn{3}{|c|}{2009 Wage } \\
\hline & & & $\Delta \varepsilon_{R}$ & Wage & Jobs & $\Delta T h_{T}$ & $\Delta T h_{R}$ & ID & U.S. \\
\hline Code & Sector & $\%$ & $\%$ & $\%$ & $\%$ & $\%$ & $\%$ & $\$$ & $\$$ \\
\hline 1003 & Securities, commodity contracts, investments & -1.7 & 0.2 & 0.0 & 0.0 & 0.4 & 0.5 & 73,462 & 177,238 \\
\hline 1200 & Professional, scientific, and technical services & -1.6 & 0.4 & -0.1 & 0.0 & -0.1 & -0.1 & 54,677 & 75,409 \\
\hline 1004 & Insurance carriers and related activities & -0.8 & 0.1 & 0.0 & 0.0 & -0.1 & -0.1 & 48,276 & 69,011 \\
\hline 1500 & Educational services & -0.8 & 0.2 & -0.1 & 0.0 & -0.1 & -0.1 & 25,523 & 36,196 \\
\hline 901 & Publishing industries, except Internet & -0.4 & 0.1 & 0.0 & -0.1 & 0.2 & 0.1 & 40,469 & 75,730 \\
\hline 1101 & Real estate & -0.4 & 0.1 & 0.0 & 0.0 & 0.0 & 0.0 & 28,841 & 43,689 \\
\hline 1903 & Membership associations and organizations & -0.4 & 0.3 & 0.0 & 0.0 & 0.0 & 0.0 & 28,831 & 34,951 \\
\hline 600 & Wholesale trade & -0.3 & 0.1 & 0.0 & 0.0 & 0.3 & 0.3 & 46,017 & 62,451 \\
\hline 902 & Motion picture and sound recording industries & -0.3 & 0.0 & 0.0 & 0.0 & 0.0 & 0.0 & 13,262 & 58,843 \\
\hline 801 & Air transportation & -0.2 & 0.1 & 0.0 & -0.1 & 0.1 & 0.1 & 39,346 & 58,409 \\
\hline 808 & Support activities for transportation & -0.2 & 0.0 & 0.0 & 0.0 & 0.0 & 0.0 & 37,890 & 47,771 \\
\hline 905 & Telecommunications & -0.2 & 0.0 & 0.1 & -0.1 & 0.0 & 0.2 & 48,495 & 71,654 \\
\hline 1002 & Credit intermediation and related activities & -0.2 & 0.5 & 0.1 & 0.1 & 0.1 & 0.1 & 42,836 & 59,768 \\
\hline 300 & Utilities & -0.1 & 0.1 & 0.0 & 0.0 & 0.1 & 0.1 & 64,720 & 86,568 \\
\hline 513 & Primary metal manufacturing & -0.1 & 0.2 & 0.1 & -0.1 & 0.1 & 0.1 & 38,524 & 55,486 \\
\hline 514 & Fabricated metal product manufacturing & -0.1 & 0.3 & 0.1 & -0.1 & 0.1 & 0.1 & 39,237 & 47,760 \\
\hline 517 & Electrical equip. and appliance manufacturing & -0.1 & 0.1 & 0.0 & -0.1 & 0.0 & 0.1 & 45,507 & 55,099 \\
\hline 542 & Plastics and rubber products manufacturing & -0.1 & 0.1 & 0.0 & -0.1 & 0.0 & 0.0 & 33,054 & 44,880 \\
\hline 706 & Health and personal care stores & -0.1 & 0.1 & 0.0 & 0.0 & 0.0 & 0.0 & 32,218 & 34,834 \\
\hline 708 & Clothing and clothing accessories stores & -0.1 & 0.0 & 0.0 & 0.0 & 0.0 & 0.0 & 15,385 & 19,180 \\
\hline 1102 & Rental and leasing services & -0.1 & 0.0 & 0.0 & 0.0 & 0.0 & 0.0 & 26,353 & 38,900 \\
\hline 1603 & Nursing and residential care facilitie & -0.1 & 0.1 & 0.0 & 0.0 & 0.0 & 0.0 & 23,071 & 27,436 \\
\hline 1702 & Museums, historical sites, zoos, and parks & -0.1 & 0.0 & 0.0 & 0.0 & 0.0 & 0.0 & 18,655 & 30,773 \\
\hline 1802 & Food services and drinking places & -0.1 & 0.2 & 0.0 & 0.0 & 0.2 & 0.2 & 13,694 & 16,768 \\
\hline 1902 & Personal and laundry services & -0.1 & 0.0 & 0.0 & 0.0 & 0.0 & 0.0 & 21,105 & 25,881 \\
\hline 512 & Nonmetallic mineral product $\mathrm{m}$ & 0.0 & 0.0 & 0.0 & 0.0 & 0.0 & 0.0 & 42,009 & 47,482 \\
\hline 532 & Beverage and tobacco product manufacturing & 0.0 & 0.0 & 0.0 & 0.0 & 0.0 & 0.0 & 41,250 & 53,326 \\
\hline 534 & Textile product mills & 0.0 & 0.0 & 0.0 & 0.0 & 0.0 & 0.0 & 27,222 & 33,524 \\
\hline 805 & Transit and ground passenger transportation & 0.0 & 0.0 & 0.0 & 0.0 & 0.0 & 0.0 & 19,668 & 29,418 \\
\hline 809 & Couriers and messengers & 0.0 & 0.0 & 0.0 & 0.0 & 0.0 & 0.0 & 37,433 & 42,540 \\
\hline 906 & ISPs, search portals, and dat & 0.0 & 0.2 & 0.1 & -0.2 & 0.3 & 0.2 & 57,142 & 77,698 \\
\hline 1103 & Lessors of nonfinancial intangible assets & 0.0 & 0.0 & 0.0 & 0.0 & 0.0 & 0.0 & 56,385 & 84,962 \\
\hline & Group C Sectors & -9.2 & 3.5 & 0.6 & -0.7 & 1.7 & 1.7 & 34,508 & 48,287 \\
\hline & Economywide & 0.0 & 0.0 & 0.3 & 1.5 & -2.8 & 0.4 & 35,023 & 45,311 \\
\hline
\end{tabular}

(C) Southern Regional Science Association 2011. 


\section{Table 10. Idaho Group D Sectors: Difference in Intertemporal and Interregional Wage and Employment Elasticities, Sector Bias, and Theil Inequality Indices and Average Wage per Job \\ (Ordered by the Rate of Interregional Growth, Lowest to Highest)}

\begin{tabular}{|c|c|c|c|c|c|c|c|c|c|}
\hline & \multirow[b]{2}{*}{ Group D Sectors: } & \multirow[b]{2}{*}{$\Delta \varepsilon_{T}$} & \multirow[b]{2}{*}{$\Delta \varepsilon_{R}$} & \multirow{2}{*}{$\begin{array}{c}\begin{array}{c}\text { Sector } \\
\text { bias } \\
\text { Wage }\end{array} \\
\end{array}$} & \multirow{2}{*}{$\begin{array}{c}\text { Sector } \\
\text { bias } \\
\text { Jobs }\end{array}$} & \multirow[b]{2}{*}{$\Delta T h_{T}$} & \multirow[b]{2}{*}{$\Delta T h_{R}$} & \multicolumn{2}{|c|}{2009 Wage } \\
\hline & & & & & & & & ID & U.S. \\
\hline Code & Sector & $\%$ & $\%$ & $\%$ & $\%$ & $\%$ & $\%$ & $\$$ & $\$$ \\
\hline 1300 & Management of companies and enterprises & -1.0 & -1.2 & -0.2 & 0.1 & -1.1 & -1.2 & 78,399 & 93,372 \\
\hline 1701 & Performing arts and spectator sports & -0.6 & -0.4 & 0.3 & 0.0 & -0.3 & 0.2 & 20,093 & 75,187 \\
\hline 541 & Chemical manufacturing & -0.5 & -0.1 & 0.0 & 0.0 & -0.1 & 0.1 & 55,612 & 81,216 \\
\hline 515 & Machinery manufacturing & -0.4 & 0.0 & 0.1 & -0.1 & 0.0 & 0.1 & 42,658 & 57,965 \\
\hline 522 & Miscellaneous manufacturing & -0.2 & 0.0 & 0.0 & 0.0 & 0.0 & 0.0 & 39,223 & 52,642 \\
\hline 811 & Warehousing and storage & -0.2 & 0.0 & 0.0 & 0.0 & 0.0 & 0.0 & 33,458 & 40,661 \\
\hline 1801 & Accommodation & -0.2 & -0.1 & 0.0 & 0.0 & 0.0 & 0.0 & 18,937 & 28,690 \\
\hline 538 & Printing and related support activities & -0.1 & -0.1 & 0.0 & 0.0 & 0.0 & 0.0 & 30,633 & 43,599 \\
\hline 903 & Broadcasting, except Internet & -0.1 & 0.0 & 0.0 & 0.0 & 0.0 & 0.0 & 35,752 & 68,743 \\
\hline 521 & Furniture and related product manufacturing & 0.0 & -0.1 & 0.0 & 0.0 & 0.0 & 0.0 & 30,943 & 37,567 \\
\hline & Group D Sectors & -3.4 & -2.1 & 0.1 & -0.1 & -1.3 & -0.8 & 42,347 & 59,650 \\
\hline & Economywide & 0.0 & 0.0 & 0.3 & 1.5 & -2.8 & 0.4 & 35,023 & 45,311 \\
\hline
\end{tabular}

U.S. $=\$ 57,964$ and Idaho $=\$ 38,571(n=17, \alpha=.025, t=2.23, p=0.02) .{ }^{12}$ The U.S. average wage per job for these high-skill/high-wage sectors is between $\$ 17,000$ and $\$ 19,000$ greater than is the Idaho average wage per job. ${ }^{13}$ The Sailing-into-the-Wind Sectors are contributing to the wage gap in Idaho both with significantly below average wages, albeit slightly improving ones, and with a decreasing rate of employment growth. Without exception, the Sailing-into-the-Wind Sectors with the most diminished influence on the state's overall wage and employment growth rate are highskill/high-wage sectors - sectors in which both wages and employment are growing nationwide. Again, based on these results, we cannot reject the possibility that the low-skill equilibrium trap theory applies to Idaho.

The low-skill equilibrium trap theory posits positive employment sector bias and difference in interregional elasticity in low-wage sectors and negative for these indicators in high-wage sectors. This is what we observe in Idaho relative to the U.S. between 2001 and 2009. See Table 5. In addition, we would expect Idaho's movement toward a low-skill equilibrium to result in a decrease in wage inequality. Again, that is what we observe: the difference in the intertemporal partial Theil inequality index between Idaho and the U.S. is -2.8 percent, which indicates a decrease in wage inequality in Idaho relative to the US. ${ }^{14}$ Group B's computer \& electronic

\footnotetext{
${ }^{12}$ We could not reject the hypothesis that the variances of the two distributions were equal.

${ }^{13}$ The comparison between foregone wages for a set of sectors and the state's average wage indicates whether actually achieving the national average wage in these sectors - if they are significantly higher — will contribute to increasing the average wage in the state.

${ }^{14}$ Because the partial-Theil index is a measure of wage inequality, a negative change in $T^{\prime}$ indicates less inequality-more wage convergence.
} 
products manufacturing sector is primarily responsible for the decrease in wage inequality because of its decreasing wage rate and the fact that it is a high-wage sector.

Fick attributed Idaho's wage gap to the loss of jobs in the natural resource sectors. This study shows that Idaho's wage gap is the result of 1) relatively more jobs in the influential lowwage sectors, 2) influential high-wage sectors with relatively fewer jobs, and 3) the high-wage sectors with much lower wages. The Idaho economy exhibits the symptoms of a low-skill equilibrium trap. The mostly low-wage/low-skill Sailing-with-the-Wind Sectors in Idahofarming, computer \& electronic product manufacturing, food manufacturing, administrative \& support services, and motor vehicle \& parts dealers - are contributing to low average wages because they are low-wage sectors that are increasing their job counts faster in Idaho than in the nation. The high-wage/high-skill Sailing-into-the-Wind Sectors-securities, commodity contracts, \& investments; professional, scientific, \& technical services; management of companies \& enterprises; educational services; and insurance carriers \& related activities - are contributing to the growing wage gap in Idaho both with significantly below average wages and with everdeclining jobs counts. In summary, Idaho's wage gap problem is broader and deeper than can be explained by the natural resource sectors alone.

From the Idaho experience, a narrative evolves that helps explain the process of economic restructuring in the Rocky Mountain region. With this narrative comes better understanding and, hopefully, better economic policies.

\section{A NEW NARRATIVE OF THE WAGE GAP FOR THE ROCKY MOUNTAIN STATES}

An analysis of wage growth between Idaho and the U.S. was performed using a secondorder Taylor-series expansion of a CES wage and employment functions, which results in a set of three indices that decompose the rate of growth in overall average wages and employment into three effects: substitution, sector bias, and technology-related residual. The data used were U.S. Bureau of Economic Analysis 2001 and 2009 wage expenditure and employment numbers for the 81 sectors that the Idaho and U.S. economies have in common.

From CES wage functions, we derived the difference between the two sets of intertemporal elasticities $\varepsilon_{R_{1} T}$ and $\varepsilon_{R_{0} T}$. This provided a set of interregional comparisons $\Delta \varepsilon_{T}$ for the influence that a change in the rate of wage growth in the sectors have had on the relative rates of growth in overall wages. With the difference in elasticities measures, sector bias and Theil inequality indices, we identified the sectors that were the source of the growing wage gap in Idaho relative to the U.S.

This study shows that the growth in Idaho's wage gap is primarily the result of positive sector bias on employment growth in influential low-wage sectors and negative sector bias on employment growth and the low level of wages in the influential high-wage sectors. Making a bad situation worse, a rapid rate of wage decline has occurred in Idaho's high-wage computer \& electronic products manufacturing sector. Thus, Idaho's economy exhibits symptoms of being in a low-skill equilibrium trap. This conclusion is further supported by Idaho's decreasing wage inequality. We infer that the Idaho results apply more generally to the Rocky Mountain region with the exception of Colorado.

High-skill economic growth depends on research and development in combination with education and training (Redding, 1996). When these complements are either absent or insufficiently available, an advanced economy can get mired in a low-skill equilibrium trap 
(Redding, 1996; Scicchitano, 2009). A role of state governments in the Rocky Mountain region is to enable their economies to move from a low- to a high-skill employment equilibrium. Thus, one goal of a government's labor policy is to raise the education and training level of people entering the labor force. For example, in the U.S. there is a lack of coordination among employers and students not choosing higher education as an option to improve skills and knowledge base (Finegold and Soskice, 1988). Government's industrial policy goal should be to provide incentives to firms that focus on product innovation, new technology, and high-quality production (Porter, 2000). Subsidizing mature industries with tax credits can be detrimental to modernizing an economy (Hayami and Godo, 2005; Markusen, 2007). Wage data suggest that Colorado's state officials have already moved their economy to a high-skill equilibrium. A question remains: will leaders in Idaho, Montana, Utah, and Wyoming help their economies follow suit?

\section{REFERENCES}

Baumol, William J. (1967) "Macroeconomics of Unbalanced Growth: The Anatomy of Urban Crisis," American Economic Review, 57, 415-426.

Bluestone, Barry and Bennett Harrison. (1988) "The Growth of Low-Wage Employment: 196386," American Economic Review, 78, 124-128.

Bound, John and George Johnson. (1992) "Changes in the Structure of Wages in the 1980's: An Evaluation of Alternative Explanations,” American Economic Review, 82, 371-391.

Card, David and John E. DiNardo. (2002) "Skill-biased Technological Change and Rising Wage Inequality: Some Problems and Puzzles," Journal of Labor Economics, 20,733-783.

Carlino, Gerald and Leonard Mills. (1996) "Convergence and the U.S. States: A Time-Series Analysis,” Journal of Regional Science, 36, 597-616.

Caves, Douglas W., Laurits R. Christensen, and W. Erwin Diewert. (1982) "The Economic Theory of Index Numbers and the Measurement of Input, Output, and Productivity," Econometrica, 50, 1393-1414.

Conceição, Pedro and James K. Galbraith. (2000) "Constructing Long and Dense Time-Series of Inequality Using the Theil Index," Eastern Economic Journal, 26, 61-74.

Deller, Steven C., Tsung-Hsiu Tsai, David W. Marcouiller, and Donald B. K. English. (2001) "The Role of Amenities and Quality of Life In Rural Economic Growth," American Journal of Agricultural Economics, 83, 352-365.

Dickie, Mark, and Shelby Gerking. (1987) “Interregional Wage Differentials: An Equilibrium Perspective," Journal of Regional Science, 27,571-585.

Diewert, W. Erwin. (1976) "Exact and Superlative Index Numbers," Journal of Econometrics, 4, $115-145$.

(1993) "Fisher Ideal Output, Input, and Productivity Indexes Revisited," Chapter 13 in W. Erwin Diewert and Alice O. Nakamura (eds.), Contributions to Economic Analysis: Essays in Index Number Theory. North-Holland, New York, pp. 71-108.

DiNardo, John, Nicole M. Fortin, and Thomas Lemieux. (1996) "Labor Market Institutions and the Distribution of Wages, 1973-1992: A Semiparametric Approach," Econometrica: Journal of the Econometric Society, 64,1001-1044. 
Evans, Alan W. (1977) "Neighborhood Externalities, Economic Clubs, and the Environment," in Alan. W. Evans and Lowden Wingo (eds.), Public Economics and the Quality of Life, Published for Resources for the Future and the Centre for Environmental Studies by the Johns Hopkins University Press: Baltimore.

Fick, Bob. (2008) "Why Idaho Wages Went South," In Bob Fick and Jean Cullen (eds.), Idaho Employment. Idaho Department of Labor: Boise, ID.

Finegold, David. (1991) "Institutional Incentives and Skill Creation: Preconditions for a HighSkill Equilibrium," in Paul Ryan (ed.), International Comparisons of Vocational Education and Training for Intermediate Skills. Falmer Press: New York, pp. 93-118.

Finegold, David and David Soskice. (1988) "The Failure of Training in Britain: Analysis and Prescription," Oxford Review of Economic Policy, 4, 21-53.

Gabriel, Stuart A. and Stuart S. Rosenthal. (2004) "Quality of the Business Environment versus Quality of Life: Do Firms and Households Like the Same Cities?," Review of Economics and Statistics, 86, 438-444.

Haskel, Jonathan E. and Matthew J. Slaughter. (2002) "Does the Sector Bias of Skill-Biased Technical Change Explain Changing Skill Premia?," European Economic Review, 46, 1757-1783.

Hayami, Yujiro and Yoshihisa Godo. (2005) Development Economics: From the Poverty to the Wealth of Nations, $3^{\text {rd }}$ ed. Oxford University Press: New York.

Heckscher, Eli F. (1955) Mercantilism. Rev. $2^{\text {nd }}$ ed. Macmillan: New York.

Juhn, Chinhui, Kevin M. Murphy, and Brooks Pierce. (1993) "Wage Inequality and the Rise in Returns to Skill," Journal of Political Economy, 101, 410-442.

Kim, Sukkoo. (1998) "Economic Integration and Convergence: U.S. Regions 1840-1987," Journal of Economic History, 58, 659-683.

Knapp, Thomas A. and Philip E. Graves. (1989) "On the Role of Amenities in Models of Migration and Regional Development," Journal of Regional Science, 29, 71-87.

Krueger, Alan B. and Lawrence H. Summers. (1988) "Efficiency Wages and the Inter-Industry Wage Structure," Econometrica, 56, 259-293.

Krugman, Paul R. (1991) "Increasing Returns and Economic-Geography," Journal of Political Economy, 99, 483-499.

Lucas, Robert. (1988) “On the Mechanics of Development Planning," Journal of Monetary Economics, 22, 3-42.

Markusen, Ann R. (2007) Reining in the Competition for Capital. W.E. Upjohn Institute for Employment Research: Kalamazoo, MI.

McGranahan, David. (1999) Natural Amenities Drive Rural Population Change. Economics Report No. 781. U.S. Department of Agriculture, Economic Research Service: Washington, D.C.

Murphy, Kevin M. and Finis Welch. (1993) "Industrial Change and the Rising Importance of Skill," in Sheldon Danziger and Peter Gottschalk (eds.), Uneven Tides: Rising Inequality in America. Russell Sage Foundation: New York, pp. 101-132. 
Nahuis, Richard. (2003) Knowledge, Inequality, and Growth in the New Economy. Edward Elgar: Northhampton, MA.

North, Douglass Cecil. (1990) Institutions, Institutional Change, and Economic Performance, The Political Economy of Institutions and Decisions. Cambridge University Press: Cambridge.

Ohlin, Bertil G. (1967) Interregional and International Trade. Harvard University Press: Cambridg, MA..

Partridge, Mark D., Dan S. Rickman, Kamar Ali, and M. Rose Olfert. (2009) "Agglomeration Spillovers and Wage and Housing Cost Gradients across the Urban Hierarchy," Journal of International Economics, 78, 126-140.

Plane, David A., Christopher J. Henrie, and Marc J. Perry. (2005) "Migration Up and Down the Urban Hierarchy and across the Life Course," Proceedings of the National Academy of Sciences of the United States of America, 102, 15313-15318.

Porter, Michael E. (2000) "Location, Competition, and Economic Development: Local Clusters in a Global Economy," Economic Development Quarterly, 14, 15-34.

Power, Thomas M. and Richard N. Barrett. (2001) Post-Cowboy Economics: Pay and Prosperity in the New American West. Island Press, Wasington, DC.

Redding, Stephen. (1996) "The Low-Skill, Low-Quality Trap: Strategic Complementarities between Human Capital and R \& D," Economic Journal, 106, 458-470.

Roback, Jennifer. (1988) "Wages, Rents, and Amenities: Differences among Workers and Regions," Economic Inquiry, 26, 23-41.

Romer, Paul M. (1986) "Increasing Returns and Long-Run Growth," Journal of Political Economy, 94, 1002-1037.

Rosen, Sherwin. (1979) "Wage-based Indexes of Urban Quality of Life," in Peter M. Mieszkowski and Mahlon R. Straszheim (eds.), Current Issues in Urban Economics. Johns Hopkins University Press: Baltimore, pp. 74-104.

Scicchitano, Sergio. (2009) "Complementarity between Heterogeneous Human Capital and R\&D: Can Job-training Avoid Low Development Traps?," Empirica, 37, 361-380.

Solow, Robert M. (1956) "A Contribution to the Theory of Economic Growth," Quarterly Journal of Economics, 70, 65-94.

Theil, Henri. (1967) Economics and Information Theory. North-Holland: Amsterdam.

United States Bureau of Economic Analysis. (2009) Local Area Personal Income and Employment Methodology. Available in February 2011 at http://www.bea.gov/regional/methods.cfm.

(2009) State Annual Personal Income. Available February 2011 at www.bea.gov/regional/spi.

United States Bureau of Labor Statistics. (2009) Consumer Price Index-All Urban Consumers. U.S. Government Printing Office. Available from February 2011 at www.bls.gov/data/. 
- (various years). Occupational Employment Statistics. Available February 2011 at http://www.bls.gov/oes/current/oes_stru.htm.

United States Census Bureau. (2011) 2005-2007 American Community Survey 3-Year Estimates. Available February 2011 at http://factfinder.census.gov/home/saff/main.html?_lang=en.

- (2010). Current Population Survey Available February 2011 at http://www.census.gov/cps/.

(2002). 2000 Decennial Census. Available February 2011 at http://factfinder.census.gov/home/saff/main.html?_lang=en.

\section{APPENDIX}

TABLE A1. Two-Sample $t$-test Assuming Unequal Variance of Average Wages in Idaho Compared to Those for the United States: 2009

\begin{tabular}{|c|c|c|c|c|c|c|}
\hline & $\begin{array}{c}\text { U.S. } \\
\text { Group A }\end{array}$ & $\begin{array}{c}\text { ID } \\
\text { Group A }\end{array}$ & $\begin{array}{c}\text { U.S. Group } \\
\text { B }\end{array}$ & $\begin{array}{c}\text { ID } \\
\text { Group B }\end{array}$ & $\begin{array}{c}\text { U.S. Group } \\
\text { C }\end{array}$ & $\begin{array}{c}\text { ID } \\
\text { Group C }\end{array}$ \\
\hline Mean & 37,464 & 30,490 & 45,427 & 40,542 & 53,864 & 36,892 \\
\hline Variance & $324,947,805$ & $181,601,104$ & $241,407,375$ & $228,248,683$ & $863,257,364$ & $221,853,298$ \\
\hline Observations & 22 & 22 & 17 & 17 & 32 & 32 \\
\hline \multicolumn{7}{|c|}{ Hypothesized Mean } \\
\hline Difference & 0 & & 0 & & 0 & \\
\hline df & 39 & & 32 & & 46 & \\
\hline t Stat & 1.45 & & 0.93 & & 2.91 & \\
\hline $\mathrm{P}(\mathrm{T}<=\mathrm{t})$ one-tail & 0.08 & & 0.18 & & 0.00 & \\
\hline \multirow[t]{2}{*}{ t Critical one-tail } & 1.68 & & 1.69 & & 1.68 & \\
\hline & $\begin{array}{c}\text { U.S. } \\
\text { Group D }\end{array}$ & $\begin{array}{c}\text { ID } \\
\text { Group D } \\
\end{array}$ & $\begin{array}{c}\text { U.S. } \\
\text { Nat. Res. }\end{array}$ & $\begin{array}{c}\text { ID } \\
\text { Nat. Res. }\end{array}$ & U.S. Overall & ID Overall \\
\hline Mean & 57,964 & 38,571 & 49,456 & 45,366 & 48,145 & 36,127 \\
\hline Variance & $446,029,465$ & $308,445,172$ & $136,039,603$ & $106,028,708$ & $576,345,143$ & $227,848,275$ \\
\hline Observations & 10 & 10 & 6 & 6 & 81 & 81 \\
\hline \multicolumn{7}{|c|}{ Hypothesized Mean } \\
\hline Difference & 0 & & 0 & & 0 & \\
\hline df & 17 & & 10 & & 135 & \\
\hline t Stat & 2.23 & & 0.64 & & 3.81 & \\
\hline $\mathrm{P}(\mathrm{T}<=\mathrm{t})$ one-tail & 0.02 & & 0.27 & & 0.00 & \\
\hline t Critical one-tail & 1.74 & & 1.81 & & 1.66 & \\
\hline
\end{tabular}

(C) Southern Regional Science Association 2011. 